\title{
Poorly controlled type 2 diabetes is accompanied by significant morphological and ultrastructural changes in both erythrocytes and in thrombin- generated fibrin: implications for diagnostics
}

\author{
Etheresia Pretorius ${ }^{1 *}$, Janette Bester ${ }^{1}$, Natasha Vermeulen ${ }^{1}$, Sajee Alummoottil ${ }^{1}$, Prashilla Soma ${ }^{1}$, \\ Antoinette $V$ Buys $^{2}$ and Douglas B Kell ${ }^{3 *}$
}

\begin{abstract}
We have noted in previous work, in a variety of inflammatory diseases, where iron dysregulation occurs, a strong tendency for erythrocytes to lose their normal discoid shape and to adopt a skewed morphology (as judged by their axial ratios in the light microscope and by their ultrastructure in the SEM). Similarly, the polymerization of fibrinogen, as induced in vitro by added thrombin, leads not to the common 'spaghetti-like' structures but to dense matted deposits. Type 2 diabetes is a known inflammatory disease. In the present work, we found that the axial ratio of the erythrocytes of poorly controlled (as suggested by increased HbA1c levels) type 2 diabetics was significantly increased, and that their fibrin morphologies were again highly aberrant. As judged by scanning electron microscopy and in the atomic force microscope, these could be reversed, to some degree, by the addition of the iron chelators deferoxamine (DFO) or deferasirox (DFX). As well as their demonstrated diagnostic significance, these morphological indicators may have prognostic value.
\end{abstract}

Keywords: Type II diabetes, Erythrocytes, Deferoxamine, Deferasirox

\section{Introduction}

Type II diabetes mellitus causes an ever-increasing burden on health care [1-4]. The prevalence for all agegroups worldwide was estimated to be $2.8 \%$ in 2000 and predicted to increase to $4.4 \%$ in 2030 [5]. Among adults in the US, the prevalence of undiagnosed diabetes is currently $4.1 \%$ and prediabetes a staggering $35.6 \%$ [6]. Type II diabetes is associated with three main glycaemic disorders: chronic hyperglycaemia; glycaemic variability; and iatrogenic hypoglycaemia [7], and also (frequently) comorbidities including dyslipidemia (high cholesterol levels) [8-11] and hypertension [12,13]. It has also been suggested that with disturbed lipid metabolism, lipid dysregulation precedes the hyperglycemia and increased

\footnotetext{
* Correspondence: resia.pretorius@up.ac.za; dbk@manchester.ac.uk ${ }^{1}$ Department of Physiology, Faculty of Health Sciences, University of Pretoria, Private Bag x323, Arcadia 0007, South Africa

${ }^{3}$ School of Chemistry and The Manchester Institute of Biotechnology, The University of Manchester, 131, Princess Street, Manchester M1 7DN, Lancs, UK Full list of author information is available at the end of the article
}

insulin resistance is found in type II diabetes [14-17]. All of the comorbidities are potentially responsible for the cardiovascular and other complications [18,19]. Compared with individuals without diabetes, patients with type II diabetes have a considerably higher risk of cardiovascular morbidity and mortality [12,20-26]. The following paragraphs will briefly discuss systemic inflammation, RBC structure and fibrin clot structure in type II diabetes.

Diabetes is associated with (low-grade) systemic inflammation [27-29]. Table 1 inflammatory markers and their respective levels, that increased or decreased in diabetes. Suggested chronological events leading to vascular dysfunction in type II diabetes are summarized in Figure 1. We know that there are important links between oxidative stress, a changed inflammatory marker profile (inflammation), the development of diabetes type II as well as, ultimately, vascular dysfunction: 
Table 1 Selected references showing a changed inflammatory marker profile in diabetes type II individuals

\begin{tabular}{ll}
\hline Inflammatory marker & Selected references \\
\hline Low Protein C & {$[36,42]$} \\
High levels of coagulation factors & {$[36,37,43-45]$} \\
(II, V, VIII, X and von Willebrandt factor) & \\
Increased NOS & {$[46-50]$} \\
Increased TNFa & {$[25,51-53]$} \\
Increased NFKB & {$[28,54-57]$} \\
Increased COX-2 & {$[57-61]$} \\
Increased PGE2 & {$[62,63]$} \\
Iron (increased serum ferritin levels) & {$[64-89]$.} \\
Increased interleukin-6 & {$[44,45,53,62,90]$} \\
Increased thromboxane A2 & {$[91,92]$} \\
\hline
\end{tabular}

- Inflammatory markers are associated with systemic oxidative stress.

- Dysregulated iron levels are known to cause oxidative stress [30-34].

- Type II diabetes and oxidative stress is closely associated with chronic inflammation [35].

- Individuals with diabetes (and cardiovascular disease) demonstrate hypercoagulability $[36,37]$ and hypercoagulability is key to inflammation [38].
- Ultimately, changed inflammatory marker levels, hypercoagulability and chronic inflammation, serve as early indicators of vascular dysfunction [39-41] see Table 1.

Erythrocytes (RBCs) and atypical fibrin fiber formation or an altered fibrin structure are particularly common in inflammation [93-98]. Also, abnormalities of high blood glucose in the context of insulin resistance, and relative insulin deficiency, may disturb the architecture and functions of RBCs at molecular scale [99]. Membrane cholesterol has also been shown to alter the fluidity and bending stiffness of RBCs $[100,101]$. Previous studies suggest that RBC rheology is also altered in type II diabetes $[102,103]$ and that hyperglycaemia has multiple effects on RBCs, including glycation of haemoglobin, reduced deformability and reduced lifespan [104]. It was also shown that an improvement in erythrocyte deformability from type II diabetes correlates with an improved glycaemic control [105]. Recently, we have also shown that RBCs in type II diabetes have a changed shape, as well as a decreased membrane roughness [93,94,106] and that RBCs can rapidly adapt in a changed environment, including during an addition of glucose to healthy RBCs [107].

Similar to changes in RBC, fibrin levels and thrombin generation are also changed, and it was indicated that

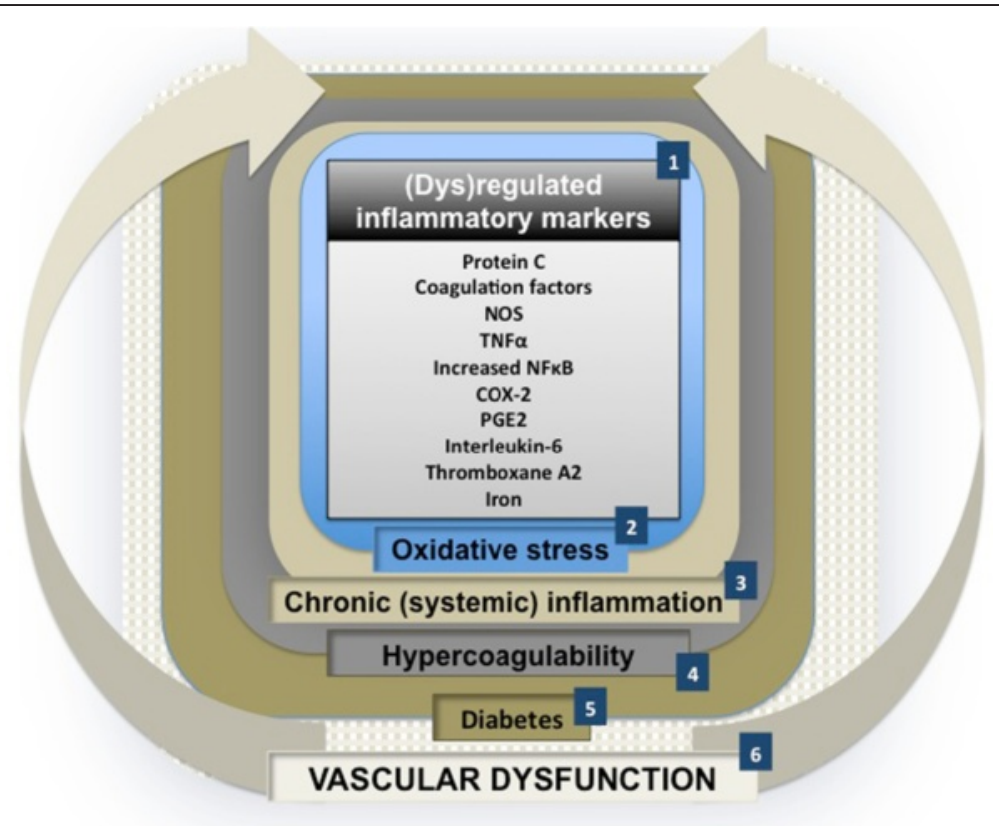

Figure 1 Suggested chronological events in type II diabetes. Inflammatory markers that are known to be dysregulated in diabetes (1); and to cause oxidative stress (2); resulting in chronic (systemic) inflammation (3); that have been associated with hypercoagulability (4). Dysregulations, as indicated by 1 to 4 have all been found in diabetes type II (5); 1 to 5 are early indicators of vascular dysfunction (6). Literature references are given in Table 1. 
Table 2 Medication typically administered to diabetes type II patients and possible effects on erythrocytes (RBCs) and fibrin clots

$\begin{array}{ll}\text { Medication Selected references } & \end{array}$

Dyslipidemia (cholesterol) medication (statins)

Simvastatin (Zocor $\left.{ }^{\oplus}\right)$ and Atorvastatin (Lipitor $\left.{ }^{\oplus}\right)$

Improve clot permeability and clot structure and enhanced fibrin clot lysis [109-113].

An increase in glycolysis metabolite concentrations and glucose-6-phosphate dehydrogenase activity in rat RBCs [114].

Increased erythrocyte fluidity $[115,116]$ and deformability $[100,117]$.

\section{Blood sugar control}

Antihyperglycemic drug dimethylbiguanide (Metformin /Glucophage $^{\oplus}$ )

Actraphane $^{\circledast}$ (mixture of fast-acting insulin and long-acting insulin)

Reversed alteration in RBC plasma membrane properties, including lipid peroxidation $[101,118]$.

Actrapid $^{\oplus}$ (human soluble insulin)

Humulin ${ }^{\circledast}$ (70\% human insulin isophane suspension and 30\% human insulin injection

[rDNA origin])

Protophane $^{\circledast}$ (intermediate-acting insulin)

\section{Hypertension control}

Coversyl $^{\circledR}$ (active ingredient is perindopril arginine which is a angiotensin converting enzyme (ACE) inhibitor)

Amlodopine $^{\circledast}$ (calcium channel blockers)

Carvedilol $^{\oplus}$ (beta and alpha adrenoceptor blocker with antioxidant activity)

Improves clot structure and hypercoagulability [119,120],

Improves clot lyses [121,122].

No evidence of any influence on RBCs or fibrin clot structure/fibrinolysis.

No evidence of any influence on RBCs or fibrin clot structure/fibrinolysis.

Improves the endothelial fibrinolytic activity [123].

Scavenger effect on free radical generator-induced RBC membrane damage [124] and enhances antioxidant defense mechanisms in RBCs [125].

Adalat $^{\circledast}$ ((nifedipine) calcium channel blocker)

Antithrombotic activity exhibitor [126] and improves fibrinolytic activity [127,128].

\section{Anti-clotting medication}

Aspirin ${ }^{\circledast}$ (acetylsalicylic acid)

Disprin $^{\circledast}$ (brand name for Aspirin)

Aspirin increases fibrin clot porosity and susceptibility to lysis [111]; antiplatelet effect [129-131]; increase the level of sphingosine-1-phosphate and ceramide in erythrocytes [129]

perturbing RBC bilayer structures [132].

Reduce risk of thrombosis [133-137].

Irreversible inhibitor of both cyclooxygenase COX-1 and COX-2 [138]. 
there is enhanced thrombin generation and formation of denser fibrin clots of reduced lysability in type II diabetes [108]. A denser clot structure therefore results both from this changed fibrin concentration and thrombin generation $[95,96]$.

Because type II diabetes is associated with dyslipidemia and hypertension, and most patients use medication to treat these co-morbidities; the medications typically prescribed are shown in Table 2. Here we also note evidence that suggests changes that the medication might have on $\mathrm{RBC}$ or fibrin structure.

We have previously shown that there are profound changes in the hematological, and in particular, the erythrocyte and coagulation system in various inflammatory conditions where iron levels are increased (particularly serum ferritin levels) (see [139-144]). In view of this, in the current work, we studied the clot structure and erythrocyte structure of patients with type II diabetes. In addition, we also investigated whether two iron chelators, deferoxamine mesylate (DFO) and deferasirox (DFX) have an effect on the RBC and fibrin clot structure.

\section{Materials and methods}

Type II diabetes and healthy individual profiles

Ethical clearance was obtained from the Health Sciences Ethical Committee of the University of Pretoria. Healthy individuals were screened and chosen to participate in the study if they did not have any chronic condition, did not smoke or if female, use any hormone replacement or contraception. Diabetic individuals were chosen randomly from the diabetic clinic at the Steve Biko Academic Hospital. The patients were diagnosed according to the SEMSDA guidelines (http://www.semdsa.org.za/images/ 2012_SEMDSA_Guideline_July_FINAL.pdf). These guidelines follow the American Diabetes Association (ADA) criteria (classification and diagnostic criteria for diabetes

Table 3 Demographic data from healthy individuals

\begin{tabular}{|c|c|c|c|c|c|c|c|c|}
\hline $\begin{array}{l}\text { Sample } \\
\text { number }\end{array}$ & Gender & Age & $\begin{array}{l}\text { Iron }\left(\mu \mathrm{mol} . \mathrm{L}^{-1}\right) \\
11.6-31.3\end{array}$ & $\begin{array}{l}\text { T Transferrin } \\
\left(\mathrm{g} . \mathrm{L}^{-1}\right) 2.2-3.7\end{array}$ & $\begin{array}{l}\% \text { saturation } \\
20-50 \%\end{array}$ & $\begin{array}{l}\text { Serum ferritin }\left(\mathrm{ng} \cdot \mathrm{mL}^{-1}\right) \\
M=20-250 \mathrm{~F}=10-120\end{array}$ & $\begin{array}{l}\text { Average axial } \\
\text { ratio }\end{array}$ & $\begin{array}{l} \pm S D \text { for } \\
\text { axial ratio }\end{array}$ \\
\hline 1 & $F$ & 45 & 16.8 & 3 & 22 & 13 & 1.15 & 0.08 \\
\hline 2 & M & 61 & 32.5 & 2.6 & 50 & 48 & 1.07 & 0.05 \\
\hline 3 & $\mathrm{~F}$ & 55 & 20 & 2.4 & 33 & 64 & 1.12 & 0.09 \\
\hline 4 & $F$ & 56 & 19.5 & 3.1 & 25 & 101 & 1.16 & 0.10 \\
\hline 5 & F & 40 & 10 & 2.8 & 14 & 21 & 1.09 & 0.06 \\
\hline 6 & F & 56 & 12.8 & 2.6 & 20 & 65 & 1.07 & 0.06 \\
\hline 7 & M & 58 & 10.2 & 2.7 & 15 & 208 & 1.09 & 0.06 \\
\hline 8 & $\mathrm{~F}$ & 48 & 17.2 & 2.8 & 25 & 37 & 1.11 & 0.06 \\
\hline 9 & F & 55 & 25.1 & 2.5 & 40 & 121 & 1.13 & 0.14 \\
\hline 10 & $\mathrm{~F}$ & 52 & 14.8 & 2.2 & 27 & 83 & 1.08 & 0.05 \\
\hline 11 & F & 45 & 31.6 & 2.7 & 47 & 111 & 1.20 & 0.16 \\
\hline 12 & $F$ & 40 & 9.6 & 2.9 & 13 & 45 & 1.11 & 0.09 \\
\hline 13 & $\mathrm{~F}$ & 80 & 7.6 & 2.7 & 11 & 21 & 1.09 & 0.07 \\
\hline 14 & M & 61 & 24.9 & 2.5 & 40 & 44 & 1.19 & 0.25 \\
\hline 15 & M & 51 & 10.8 & 2.8 & 15 & 140 & 1.10 & 0.08 \\
\hline 16 & M & 70 & 17 & 2.9 & 23 & 198 & 1.32 & 0.24 \\
\hline 17 & M & 66 & 29.5 & 2.8 & 42 & 72 & 1.10 & 0.10 \\
\hline 18 & M & 61 & 7 & 2.2 & 13 & 233 & 1.16 & 0.19 \\
\hline 19 & $M$ & 56 & 16.2 & 1.7 & 38 & 138 & 1.14 & 0.12 \\
\hline 20 & $F$ & 58 & 13.6 & 2.4 & 23 & 95 & 1.11 & 0.09 \\
\hline 21 & $F$ & 51 & 24.2 & 3.3 & 29 & 26 & 1.13 & 0.12 \\
\hline 22 & $F$ & 58 & 15.9 & 2.4 & 27 & 65 & 1.12 & 0.09 \\
\hline 23 & $F$ & 27 & 21.2 & 2.6 & 33 & 28 & 1.14 & 0.09 \\
\hline 24 & $M$ & 75 & 14.9 & 2.3 & 26 & 393 & 1.19 & 0.19 \\
\hline 25 & $\mathrm{~F}$ & 56 & 20.2 & 2.9 & 28 & 159 & 1.12 & 0.13 \\
\hline
\end{tabular}

Bold values are above and italic values below the reference (normal) range. 
Table 4 Demographics, iron, HbA1c levels and medication usage of Type II diabetes patients

\begin{tabular}{|c|c|c|c|c|c|c|c|c|c|c|c|c|}
\hline $\begin{array}{l}\text { Sample } \\
\text { number }\end{array}$ & Gender & Age & $\begin{array}{l}\text { Iron }\left(\mu \mathrm{mol} . \mathrm{L}^{-1}\right) \\
11.6-31.3\end{array}$ & $\begin{array}{l}\text { Transferrin } \\
\left(\text { g. } \mathrm{L}^{-1}\right) \text { 2.2-3.7 }\end{array}$ & $\begin{array}{l}\% \text { saturation } \\
20-50 \%\end{array}$ & 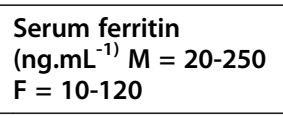 & $\begin{array}{l}\text { HbA1c } \\
(\%)<7 \%\end{array}$ & $\begin{array}{l}\text { Dyslipidemia: } \\
\text { Simvastatin } \\
\text { Atorvastatin } \\
\end{array}$ & $\begin{array}{l}\text { Met-formin/ } \\
\text { Oral }\end{array}$ & $\begin{array}{l}\text { Actrapid Humulin } \\
\text { Protoph-ane } \\
\text { Actra-phane }\end{array}$ & $\begin{array}{l}\text { HT: Coversyl } \\
\text { Amlodopine } \\
\text { Carvedilol Adalat }\end{array}$ & $\begin{array}{l}\text { Aspirin/ } \\
\text { Disprin }\end{array}$ \\
\hline 1 & $M$ & 68 & 25.5 & 3.6 & 28 & 67 & & $x$ & $x$ & & $x$ & $x$ \\
\hline 2 & M & 56 & 49 & 3 & 65 & 86 & 11.9 & & $x$ & & $x$ & \\
\hline 3 & M & 71 & 28.1 & 2.2 & 51 & 210 & 8.3 & & $x$ & & $x$ & \\
\hline 4 & M & 80 & 15.5 & 2.6 & 24 & 96 & 7 & $x$ & $x$ & & $x$ & $x$ \\
\hline 5 & M & 37 & 18.5 & 2.8 & 26 & 191 & 7.6 & & $x$ & & & \\
\hline 6 & M & 56 & 10.6 & 2.7 & 16 & 39 & 7.7 & & $x$ & & $x$ & \\
\hline 7 & $\mathrm{~F}$ & 71 & 19.9 & 2.3 & 35 & 20 & 8 & $x$ & $x$ & & $x$ & $x$ \\
\hline 8 & $\mathrm{~F}$ & 48 & 15.1 & 3.3 & 18 & 46 & 6.2 & $x$ & $x$ & & $x$ & $x$ \\
\hline 9 & $\mathrm{~F}$ & 70 & 5.2 & 3.9 & 5 & 7 & 7.5 & & $x$ & & $x$ & \\
\hline 10 & $F$ & 82 & 33.6 & 3 & 45 & 101 & 8.9 & $x$ & $x$ & & $x$ & $x$ \\
\hline 11 & M & 62 & 25.6 & 2.3 & 45 & 202 & 5.9 & & $x$ & & $x$ & \\
\hline 12 & M & 71 & 17.8 & 2.4 & 30 & 243 & 10.5 & $x$ & $x$ & & $x$ & x \\
\hline 13 & M & 70 & 19.7 & 2.2 & 36 & 75 & 10.4 & & $x$ & & $x$ & \\
\hline 14 & $\mathrm{~F}$ & 58 & 36.5 & 2.9 & 50 & 164 & 6.0 & & $x$ & & & \\
\hline 15 & $F$ & 61 & 18.6 & 2.8 & 27 & 29 & 8.2 & & $x$ & & $x$ & \\
\hline 16 & M & 56 & 32.1 & 2.9 & 44 & 152 & 8.6 & $x$ & $x$ & & $x$ & $x$ \\
\hline 17 & M & 42 & 40.7 & 2.3 & 71 & 217 & 13.6 & & $x$ & & & \\
\hline 18 & $F$ & 62 & 16.2 & 4.1 & 16 & 24 & 10.6 & $x$ & $x$ & & $x$ & $x$ \\
\hline 19 & M & 72 & 19.8 & 2.1 & 38 & 332 & 6.7 & & $x$ & $x$ & $x$ & x \\
\hline 20 & M & 59 & 18.5 & 2.8 & 26 & 191 & $?$ & $x$ & $x$ & & & \\
\hline 21 & M & 75 & 14 & 1.7 & 33 & 218 & 6.6 & & $x$ & $x$ & $x$ & $x$ \\
\hline 22 & M & 41 & 28.2 & 3 & 38 & 235 & 8.3 & $x$ & $x$ & $x$ & & $x$ \\
\hline 23 & $F$ & 81 & 23.8 & 2.3 & 41 & 62 & 9 & $x$ & & $x$ & $x$ & $x$ \\
\hline 24 & $M$ & 41 & 33.4 & 2.7 & 49 & 101 & 5.5 & $x$ & $x$ & $x$ & & $x$ \\
\hline 25 & $M$ & 80 & 39.5 & 2.7 & 59 & 142 & 6.8 & $x$ & $x$ & & $x$ & \\
\hline 26 & $M$ & 64 & 13.2 & 2.3 & 23 & 50 & $?$ & & $x$ & $x$ & & \\
\hline 27 & $M$ & 63 & 22.9 & 2.4 & 38 & 265 & 10.2 & $x$ & $x$ & $x$ & $x$ & $x$ \\
\hline 28 & $\mathrm{~F}$ & 49 & 7.1 & 3.4 & 8 & 12 & 6.8 & $x$ & $x$ & $x$ & $x$ & \\
\hline 29 & $M$ & 72 & 25.3 & 2.4 & 42 & 386 & 6.7 & & $x$ & $x$ & $x$ & $x$ \\
\hline 30 & $M$ & 46 & 21 & 2.4 & 35 & 233 & 11.6 & & $x$ & & & \\
\hline
\end{tabular}


Table 4 Demographics, iron, HbA1c levels and medication usage of Type II diabetes patients (Continued)

\begin{tabular}{|c|c|c|c|c|c|c|c|c|c|c|c|c|}
\hline 31 & M & 40 & 14.5 & 2.4 & 24 & 96 & 8.7 & & & $\bar{x}$ & $x$ & \\
\hline 32 & M & 55 & 10.3 & 2.2 & 19 & 88 & 5.8 & & $x$ & $x$ & $x$ & \\
\hline 33 & $\mathrm{~F}$ & 62 & \multicolumn{4}{|c|}{ BLOOD CLOTTED } & 8.2 & $x$ & & & $x$ & \\
\hline 34 & M & 52 & 25.9 & 3 & 35 & 155 & & & $x$ & & $x$ & \\
\hline 35 & $F$ & 59 & 18.5 & 2.5 & 30 & 125 & 11.6 & $x$ & & $x$ & $x$ & \\
\hline 36 & $\mathrm{~F}$ & 58 & 16.5 & 2.5 & 26 & 79 & 6.0 & $x$ & $x$ & $x$ & $x$ & $x$ \\
\hline 37 & $\mathrm{~F}$ & 62 & 14.1 & 2.9 & 19 & 64 & 10.2 & $x$ & $x$ & $x$ & $x$ & \\
\hline 38 & M & 60 & 6.1 & 2.6 & 9 & 93 & 7.5 & $x$ & $x$ & $x$ & $x$ & $x$ \\
\hline 39 & $F$ & 57 & 24 & 2.7 & 36 & 60 & 8.0 & $x$ & $x$ & $x$ & $x$ & $x$ \\
\hline 40 & $F$ & 63 & 31.4 & 2.5 & 50 & 77 & 7.6 & $x$ & $x$ & $x$ & $x$ & \\
\hline 41 & M & 59 & 15.4 & 2.8 & 22 & 151 & 8.5 & $x$ & & $x$ & $x$ & $x$ \\
\hline 42 & M & 73 & 29.5 & 2.9 & 51 & 154 & 8.0 & $x$ & & $x$ & $x$ & \\
\hline 43 & $F$ & 58 & 20.3 & 2 & 41 & 81 & 10.6 & $x$ & $x$ & $x$ & $x$ & \\
\hline 44 & $F$ & 66 & 28.6 & 2.6 & 44 & 359 & 10.0 & $x$ & $x$ & $x$ & $x$ & \\
\hline 45 & $M$ & 60 & 18 & 2.4 & 30 & 192 & 12.2 & $x$ & $x$ & $x$ & $x$ & \\
\hline 46 & $\mathrm{~F}$ & 69 & 9.6 & 2.3 & 17 & 74 & 7.4 & $x$ & $x$ & $x$ & $x$ & \\
\hline 47 & $M$ & 62 & 21.1 & 3.1 & 27 & 28 & 9.2 & $x$ & $x$ & & $x$ & \\
\hline 48 & $M$ & 58 & 28.2 & 2.8 & 40 & 605 & 11.9 & $x$ & $x$ & $x$ & $x$ & $x$ \\
\hline 49 & $\mathrm{~F}$ & 62 & 12.4 & 2.2 & 23 & 58 & 11.3 & $x$ & $x$ & & $x$ & $x$ \\
\hline 50 & $M$ & 61 & 23 & 1.9 & 48 & 1097 & 6.9 & $x$ & & $x$ & $x$ & $x$ \\
\hline 51 & $M$ & 73 & 54.9 & 2.4 & 92 & 100 & & $x$ & $x$ & & $x$ & $x$ \\
\hline 52 & $F$ & 45 & 8 & 3.7 & 9 & 9 & 11.6 & $x$ & & $x$ & $x$ & $x$ \\
\hline 53 & $\mathrm{~F}$ & 62 & 42.3 & 2.4 & 71 & 198 & 8 & & $x$ & & $x$ & \\
\hline 54 & $F$ & 53 & \multicolumn{4}{|c|}{ BLOOD CLOTTED } & 10.9 & $x$ & & $x$ & $x$ & $x$ \\
\hline 55 & $F$ & 55 & 13.1 & 2.2 & 24 & 189 & 6.3 & $x$ & $x$ & $x$ & $x$ & $x$ \\
\hline 56 & M & 56 & 27 & 2.6 & 42 & 64 & 12.1 & $x$ & $x$ & $x$ & $x$ & \\
\hline 57 & $\mathrm{~F}$ & 70 & 17.8 & 3 & 24 & 23 & 11.6 & $x$ & & $x$ & $x$ & $x$ \\
\hline 58 & $\mathrm{~F}$ & 59 & 34.1 & 2.7 & 51 & 56 & 5.8 & $x$ & $x$ & & $x$ & $x$ \\
\hline 59 & M & 66 & 32.3 & 2.7 & 48 & 123 & 11.9 & $x$ & $x$ & $x$ & $x$ & $x$ \\
\hline 60 & $F$ & 54 & \multicolumn{4}{|c|}{ BLOOD CLOTTED } & 15.1 & $x$ & & $x$ & $x$ & \\
\hline 61 & M & 65 & 19.3 & 2.8 & 28 & 57 & 7.0 & $x$ & & $x$ & $x$ & \\
\hline 62 & $\mathrm{~F}$ & 56 & 16.6 & 2.6 & 26 & 24 & 11.1 & $x$ & $x$ & $x$ & $x$ & \\
\hline
\end{tabular}


Table 4 Demographics, iron, HbA1c levels and medication usage of Type II diabetes patients (Continued)

\begin{tabular}{|c|c|c|c|c|c|c|c|c|c|c|c|c|}
\hline 63 & $\mathrm{~F}$ & 59 & 20.4 & 3.6 & 23 & 149 & & & & & & \\
\hline 64 & $\mathrm{~F}$ & 64 & 7.3 & 2.3 & 13 & 82 & 9.0 & & & $x$ & $x$ & $\mathrm{x}$ \\
\hline 65 & $\mathrm{M}$ & 32 & 16.8 & 3.2 & 21 & 58 & & & & & & \\
\hline 66 & M & 52 & 129.6 checked & 3.2 & $>95$ & 55 & 8.1 & $x$ & $x$ & $x$ & $x$ & $x$ \\
\hline 67 & M & 52 & 14.5 & 2.3 & 25 & 151 & 12.2 & $x$ & & $x$ & $x$ & \\
\hline 68 & $\mathrm{~F}$ & 49 & 14.2 & 2.7 & 21 & 17 & 13.5 & & $x$ & & $x$ & \\
\hline 69 & $\mathrm{~F}$ & 42 & 6 & 3.4 & 7 & 9 & 8.3 & $x$ & $x$ & $x$ & $x$ & \\
\hline
\end{tabular}

Normal (healthy values) is given in the heading. Bold values are above and italic values below the reference (normal) range. 
Table 5 Average axial ratios of the groups and significant differences between the groups

\begin{tabular}{|c|c|c|c|c|c|}
\hline \multirow[b]{2}{*}{ Average age and \pm SD } & \multirow{2}{*}{$\begin{array}{l}\text { Healthy individuals } \\
\text { (no products added) }(\mathrm{N}=\mathbf{2 5}) \\
55 \pm 11\end{array}$} & \multirow{2}{*}{$\begin{array}{l}\begin{array}{l}\text { Untreated Diabetes } \\
\text { (DIAB) }(\mathrm{N}=69)\end{array} \\
59 \pm 11\end{array}$} & \multirow[t]{2}{*}{$\begin{array}{l}\text { Diabetes with Deferasirox } \\
(\mathrm{DFX})(\mathrm{N}=69)\end{array}$} & \multicolumn{2}{|c|}{$\begin{array}{l}\text { Diabetes with Deferoxamine } \\
\text { (DFO) }(\mathrm{N}=69)\end{array}$} \\
\hline & & & & & \\
\hline Cells analysed $(\mathrm{N})$ & 3265 & 4365 & 4271 & 4369 & \\
\hline Axial ratio average and \pm SD & $1.14 \pm 0.15$ & $1.25 \pm 0.27$ & $1.24 \pm 0.26$ & $1.27 \pm 0.27$ & \\
\hline \multicolumn{6}{|c|}{ SIGNIFICANT DIFFERENCE BETWEEN GROUPS ( $p$-values shown) } \\
\hline Healthy/Diab & Diab/DFX & Diab/DFO & DFX/DFO & Healthy/DFX & Healthy/DFO \\
\hline $1.1 \mathrm{E}-56$ & 4.7E-02 & 2.6E-04 & $2.6 \mathrm{E}-04$ & $2.9 \mathrm{E}-83$ & 2.0E-02 \\
\hline
\end{tabular}

Data provided for healthy individuals compared with untreated diabetes, diabetes treated with deferasirox (DFX) and deferoxamine (DFO). Untreated diabetes results were also compared (comparison done on a paired basis) with diabetes treated with DFX and DFO.

were proposed by the American Diabetes Association) to define type II diabetes $[145,146]$. Citrated blood was collected for morphology studies and full iron profiles tests were done on both healthy and diabetic individuals. Plasma iron levels, HbA1c (Hemoglobin Alc) and medication were noted for each of the diabetes individuals (discussed later in detail in tables).

\section{Chelator addition to blood samples}

Microscopy techniques were done with blood from diabetic patients with and without the addition of deferoxamine (DFO) and deferasirox (DFX), and with and without the addition of thrombin (final concentration chelator in whole blood were $3.33 \mathrm{mM}$ and where thrombin was added, was $2.5 \mathrm{mM}$ ). To ensure a significant effect, we added an excess of each chelator; stoichiometric principles will ensure the full chelation of any unliganded iron present in whatever form. The solvent for both the chelators was $\mathrm{DD} \mathrm{H}_{2} \mathrm{O}$. Chelators were added to whole blood (WB) and left to react for 3 minutes. The kinetics of the chelators are virtually instantaneous and the potential for sequestration of the chelators by e.g. albumin is precisely why we added an excess of these reagents. When thrombin is added an extensive fibrin network is created around trapped RBCs. These
WB preparation methods were done for all microscopy techniques (described in the following paragraphs).

\section{Light microscopy of erythrocytes}

LM was used to study the axial ratios of RBCs, using $100 \times$ magnification (with and without DFX and DFO). 10ul of WB was used to make a thin smear on a microscopic glass slide, this smear was left for 24 hours to air dry followed by fixing for 5 minutes in $100 \%$ methanol and left to air dry for 30 minutes. The smears were stained again for 4 minutes with Löffler's methylene blue, and rinsed under running water followed by airdrying for 30 minutes. The final staining step involved staining for 30 seconds in Eosin Y-solution 0.5\% aqueous, and rinsing with running water. Slides were viewed using a Nikon Optiphod transmitted light microscope.

\section{Axial ratio determination of erythrocyte shape}

Axial ratios were determined from the LM micrographs, with the use of a program written in the C\# programming language. The longest axis from each $\mathrm{RBC}$ was determined, referred to as the major axis, after which a perpendicular line was drawn in the centre of the major axis to establish the minor axis length. The axial ratio for each cell was obtained by dividing the major axis

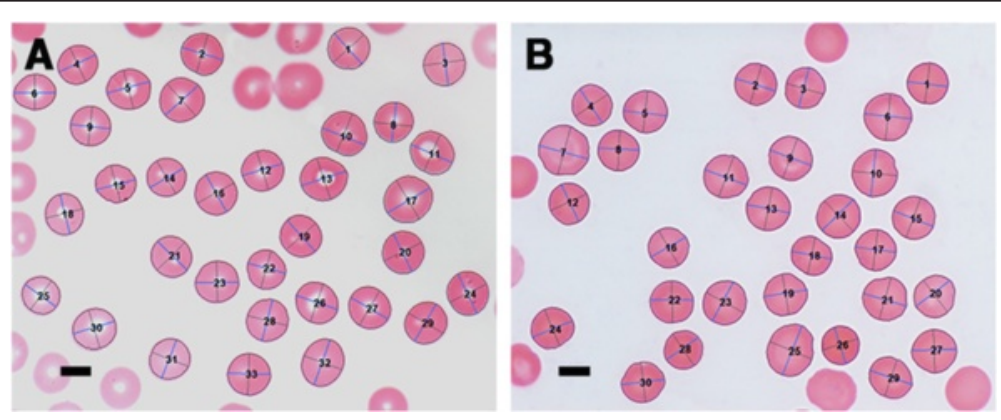

Figure 2 Blood smears from two healthy individuals, showing axial ratio positions used for calculations. A) Male: 60 ; serum ferritin: 48 ng. $\mathrm{mL}^{-1}$ B) male: 58 ; serum ferritin: $208 \mathrm{ng} \cdot \mathrm{mL}^{-1}$. Scale bar $=5 \mu \mathrm{M}$. 
length by the minor axis length; a value of 1 represents a perfect circle.

\section{Scanning electron microscopy (SEM) of erythrocytes}

High magnification SEM analyses were used to look at RBC structure and membrane surface. $20 \mu \mathrm{L}$ of the fixed WB was dropped on a small glass coverslip to make smears, dehydrated, dried, mounted and coated with carbon according to previously described methods [93]. A Zeiss ULTRA Plus FEG-SEM with InLens capabilities was used to study the surface morphology of erythrocytes, and micrographs were taken at $1 \mathrm{kV}$.

\section{Atomic force microscopy of erythrocytes}

Sample preparation was done according to previously described methods [143]. Characterization of RBCs was performed with a commercial AFM system (Dimension Icon with ScanAsyst, Bruker, USA) using the PeakForce QNM (Quantitative Nanomechanical Property Mapping) imaging mode [147]. At every pixel point a rapid force-
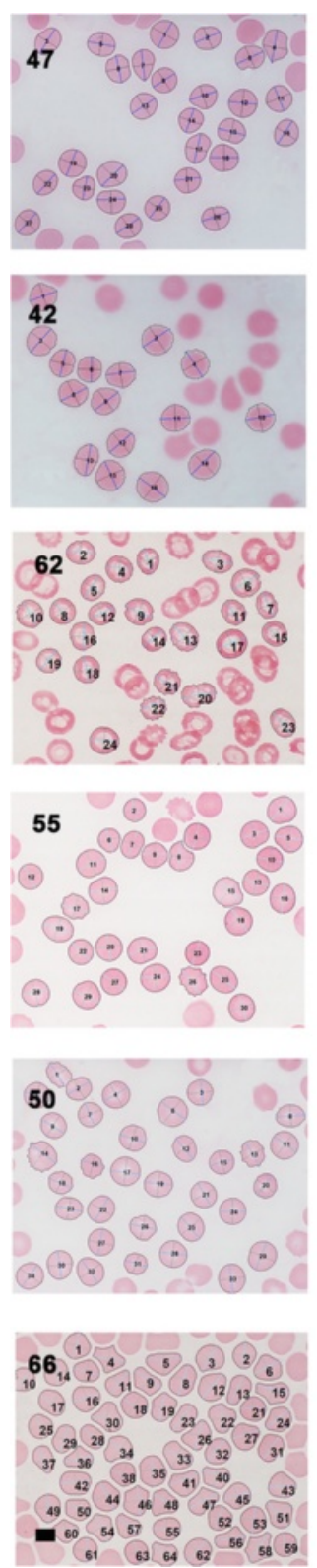
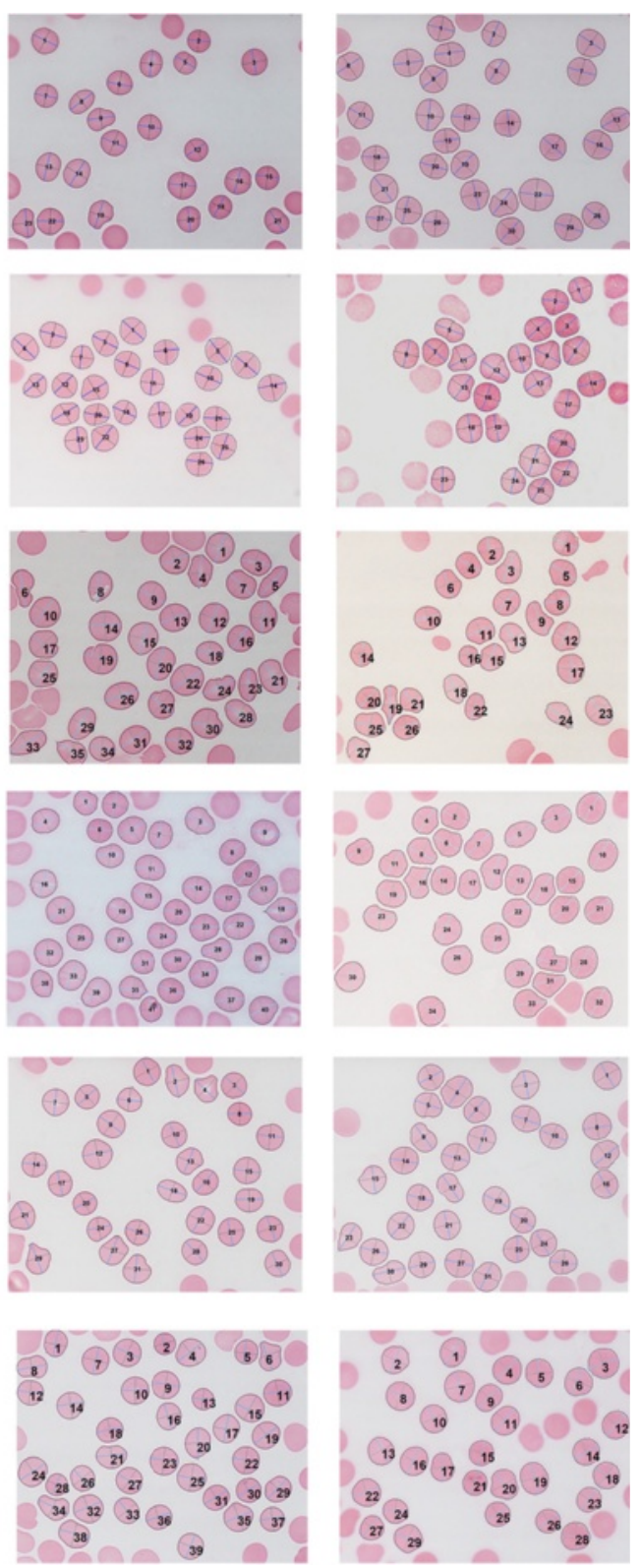

Figure 3 Light microscopy smears of diabetic patients before and after treatment. Left: untreated; middle: treated with deferasirox (DFX) and right: treated with deferoxamine (DFO). Patient detail is shown in Table 6. Scale bar $=5 \mu \mathrm{M}$. 
distance curve is performed and as the cantilever's deflection sensitivity and spring constant is calibrated before measurements, the curve can be analysed quantitatively to obtain a series of specific property maps of the sample. A retract curve is used to calculate modulus and adhesion images (slope of the curve and the minimum of the curve respectively) $[141,143,148]$, the variation between the zero and maximum force is used to calculate deformation and the area between the approach and retract curve can be used to calculate energy dissipation [149]. The slope of the curve was fit, using the Derjaguin-Muller-Toporov (DMT) Model to determine the Young's modulus (a measure of the stiffness of an elastic material) $[141,150]$. Silicon Nitride probes (TAP525 - MPP 13120-10, Bruker, USA) with a nominal force constant of $200 \mathrm{~N} . \mathrm{m}-1$, a resonant frequency between 430 and $516 \mathrm{kHz}$ (measured by the manufacturer), and a nominal tip radius of $15 \mathrm{~nm}$ were employed in all AFM measurements.

From the diabetes sample, RBCs from the first 22 diabetic patients were analysed using AFM analysis, before and after exposure to the 2 chelators. Ten cells from each sample were analysed by selecting a $1 \mu \mathrm{m}$ by $1 \mu \mathrm{m}$ scan area on the periphery of the RBC and performing 128 by 128 data points of individual force curve measurements with a peak force of $6 \mu \mathrm{N}$. The periphery of the cells was chosen as not to be affected by the possible differences in concavity of the RBCs. The scans were performed at $0.6 \mathrm{~Hz}$, which translates to a tip velocity of $1.2 \mu \mathrm{m} / \mathrm{s}$ and 50 force curves were chosen randomly within the stated area. Offline software (NanoScope Analysis version R3, Bruker, USA) was used to process the force curves and fit the modulus model to the unloading portion of the curve. The goodness of fit (R2) between the modulus model and the data given by the acquired curve is determined by calculating the ratio of explained variation to total variation in the dataset; only force curves with a goodness of fit so defined of 0.85 and above were used for modulus measurements. The statistical significance of the difference between calculations was determined using one-way analysis of variance. A P-value of less than 0.05 relative to the null hypothesis was considered to be 'significant' (cf. [151]), P-values are noted and boxplots drawn, together with descriptive statistics. A box plot was calculated using MS-Excel, together with the add-in template downloadable from http://www.vertex42.com/.

\section{Scanning electron microscopy of fibrin networks}

$10 \mu \mathrm{L}$ platelet rich plasma (PRP) was mixed with $10 \mu \mathrm{L}$ human thrombin provided by the South African Blood services. Extensive fibrin fiber networks were created

Table 6 Diabetes patient detail for light microscopy axial ratio micrographs, shown in Figure 3

\begin{tabular}{|c|c|c|c|c|c|c|c|c|c|}
\hline & $\begin{array}{l}\text { AVERAGE } \\
\text { AXIAL RATIOS }\end{array}$ & P1 & P2 & Gender & Age & $\begin{array}{l}\text { Iron }\left(\left(\mu \mathrm{mol} . \mathrm{L}^{-1}\right)\right. \\
11.6-31.3\end{array}$ & $\begin{array}{l}\text { Transferrin } \\
\left(\mathrm{g} . \mathrm{L}^{-1}\right) \text { 2.2-3.7 }\end{array}$ & $\begin{array}{l}\% \text { saturation } \\
20-50 \%\end{array}$ & $\begin{array}{l}\text { Serum ferritin }\left(\mathrm{ng} \cdot \mathrm{mL}^{-1}\right) \\
M=20-250 \mathrm{~F}=10-120\end{array}$ \\
\hline DIABETES 47 & 1.24 & 0.006 & 0.009 & $M$ & 62 & 21.1 & 3.1 & 27 & 28 \\
\hline DFX & 1.15 & & & & & & & & \\
\hline DFO & 1.17 & & & & & & & & \\
\hline DIABETES 42 & 1.14 & 0.05 & 0.28 & M & 73 & 29.5 & 2.9 & 51 & 154 \\
\hline DFX & 1.14 & & & & & & & & \\
\hline DFO & 1.17 & & & & & & & & \\
\hline DIABETES 62 & 1.24 & 0.25 & $4.2 \times 10^{-7}$ & $\mathrm{~F}$ & 56 & 16.6 & 2.6 & 26 & 24 \\
\hline DFX & 1.28 & & & & & & & & \\
\hline DFO & 1.45 & & & & & & & & \\
\hline DIABETES 55 & 1.16 & 0.035 & 0.001 & $\mathrm{~F}$ & 55 & 13.1 & 2.2 & 24 & 189 \\
\hline DFX & 1.21 & & & & & & & & \\
\hline DFO & 1.25 & & & & & & & & \\
\hline DIABETES 50 & 1.18 & 0.035 & 0.73 & M & 61 & 23 & 1.9 & 48 & 1097 \\
\hline DFX & 1.14 & & & & & & & & \\
\hline DFO & 1.17 & & & & & & & & \\
\hline DIABETES 66 & 1.33 & $5.8 \times 10^{-7}$ & $3.9 \times 10^{-7}$ & M & 52 & 129.6 & 3.2 & $>95$ & 55 \\
\hline DFX & 1.15 & & & & & & & & \\
\hline DFO & 1.11 & & & & & & & & \\
\hline
\end{tabular}

P-values: P1 (axial ratios of untreated diabetes RBCs versus DFX-treated) and P2 (axial ratios of untreated diabetes RBCs versus DFO-treated) (significant p-value was taken as $\leq 0.05$; comparisons done on a paired basis) (Figure 3). Bold values are above and italic values below the reference (normal) range. 
A

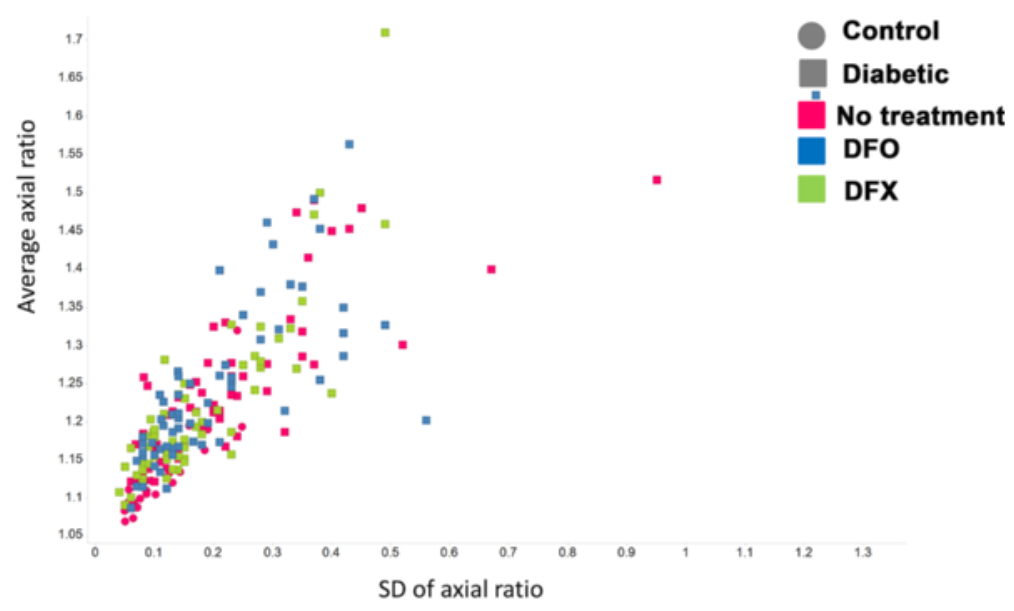

B

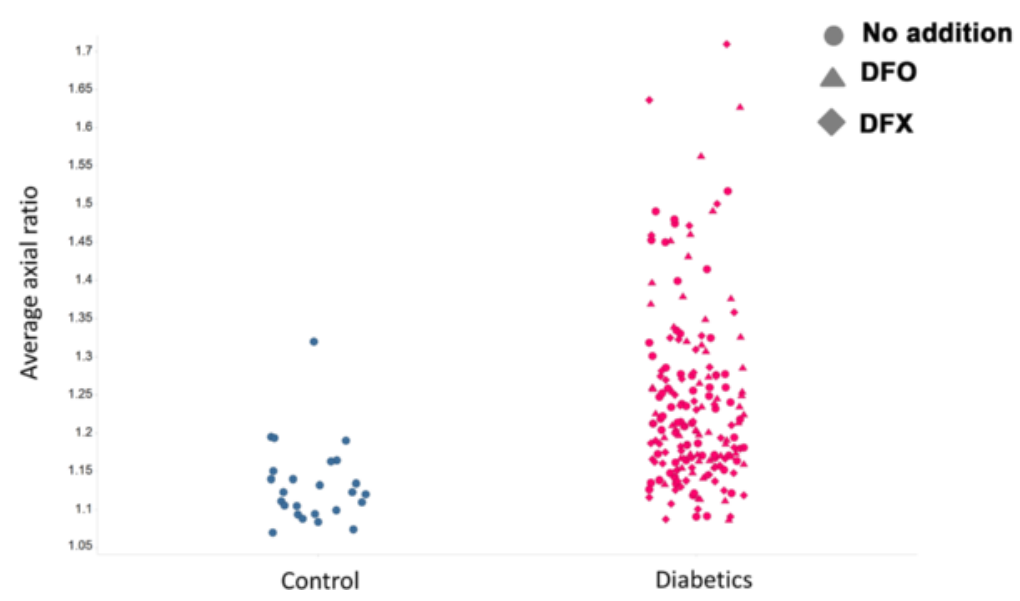

Figure 4 Axial ratios of the erythrocytes from controls and diabetics. As indicated in Table 5, there were significant differences in the axial ratios of diabetes vs controls, whether iron chelators were present or absent. A. Relationship between axial ratio and its standard deviation. B. Direct comparison between patients and controls. In $\mathbf{B}$ the values on the abscissa (only) are 'jittered' to make them easier to see.

and smears washed and fixed in $4 \%$ formaldehyde. Smears were prepared as described for RBCs and also viewed using Zeiss ULTRA Plus FEG-SEM with InLens capabilities. Fibrin fiber thickness were measured with ImageJ (Image I is a public domain, Java-based image processing program developed at the National Institutes of Health: http://rsbweb.nih.gov/ij/).

\section{Results}

This study used 25 age- and gender-controlled healthy individuals (see Table 3) and 69 individuals with type II diabetes. The average age of healthy individuals was $55(\mathrm{SD} \pm 11)$, while the average age of the diabetic individuals was $59(\mathrm{SD} \pm 11)$. The current randomly selected type II diabetic population, in addition to their anti-diabetic medication, are on medication for

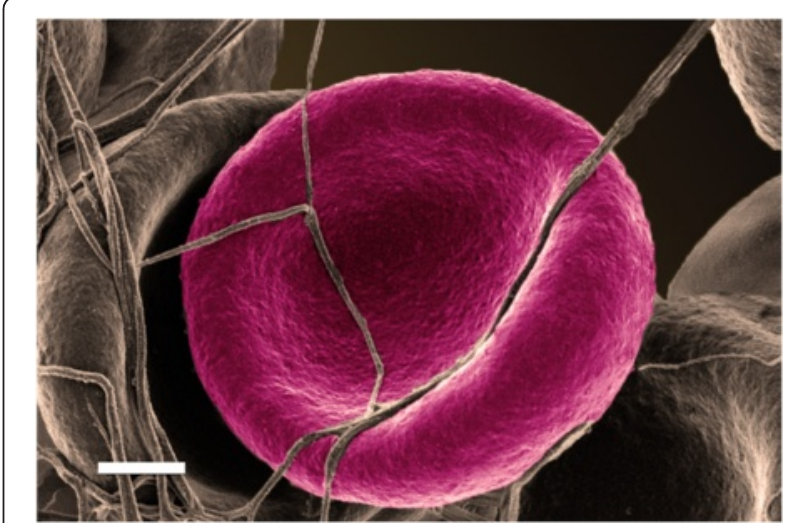

Figure 5 Whole blood of healthy individual, with added thrombin, to create an extensive fibrin network around RBCs. Male: 61; serum ferritin: $48 \mathrm{ng} \cdot \mathrm{mL}^{-1}$. Scale Bar $=1 \mu \mathrm{M}$. 
dyslipidemia and hypertension as well (see Table 4). Despite their anti-diabetic medications, very few individuals showed HbA1c (Hemoglobin Alc) within the normal ranges, suggesting poorly controlled diabetes. In some patients, there were also abnormal iron levels (Table 4).

\section{Light microscopy}

Light microscopy of smears from typical healthy individuals, with their axial ratio positions indicated, is shown in Figure 2. Light microscopy statistics of the average RBC axial ratios of within group analysis are shown in Table 5. Figure 3 shows smears from diabetes patients
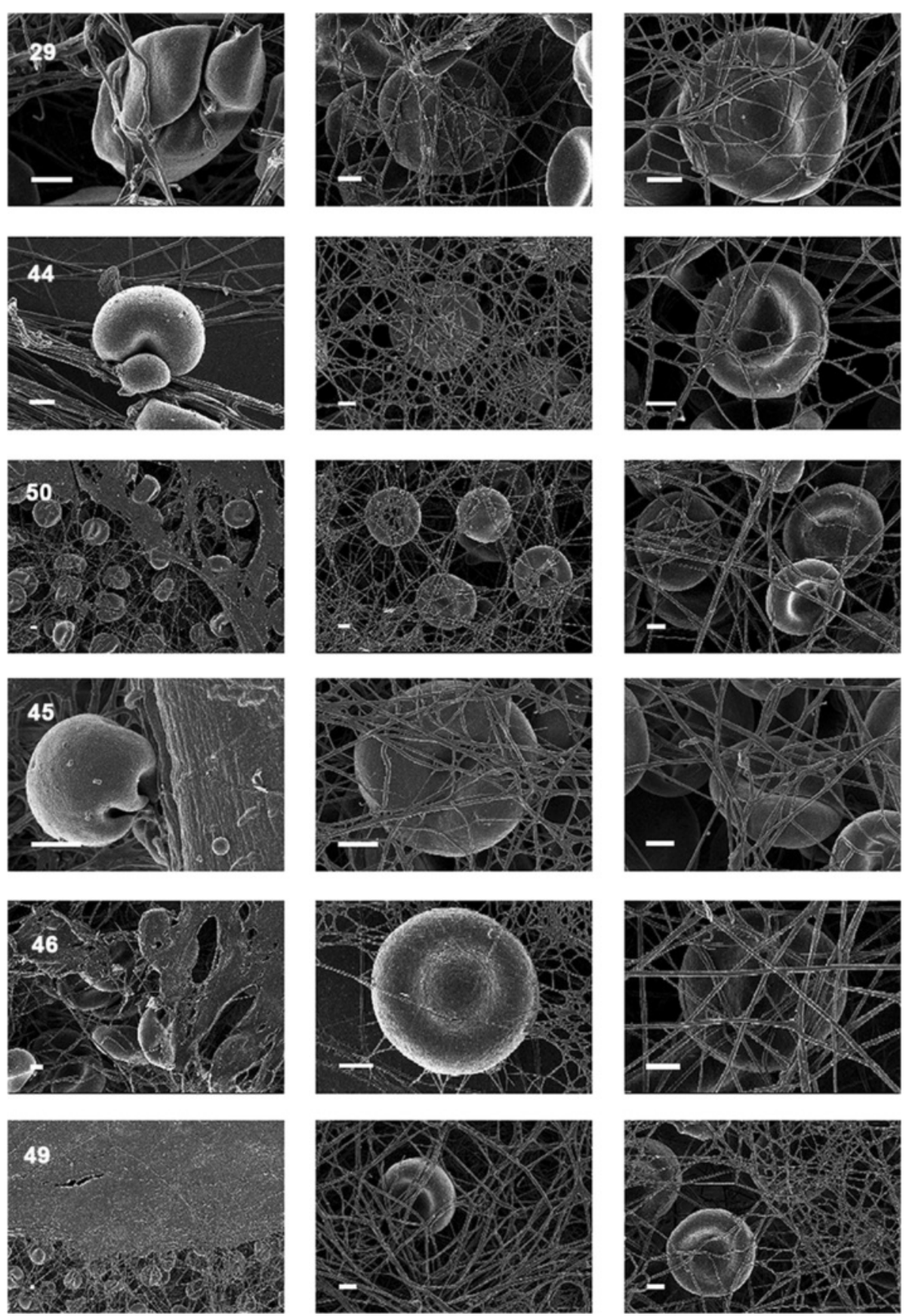

Figure 6 Whole blood from diabetic patients before and after treatment. Left: untreated; middle: Deferasirox (DFX) and right: deferoxamine (DFO). Table 7 shows the detail of the diabetic patients (sample numbers of diabetic patients shown on micrographs) shown in this figure. Scale Bar $=1 \mu \mathrm{M}$. 


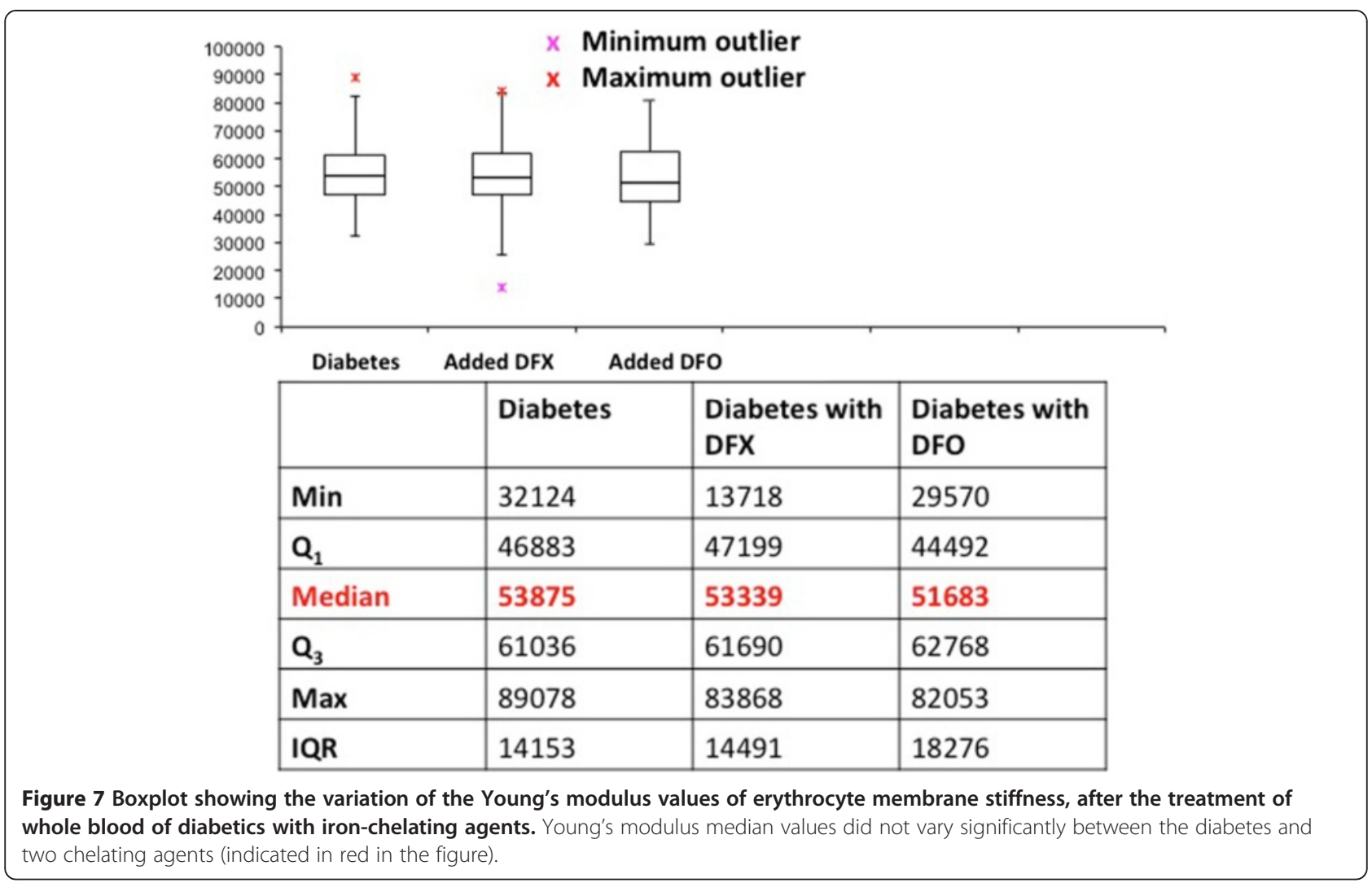

before and after treatment with the 2 chelators (left: untreated diabetes; middle: DFX; right: DFO) Smears were chosen that represents the sample, e.g. normal iron levels, increased iron levels and whether addition of chelators showed a significant P-value (or not) (see Table 6); for specific details of the patients shown in Figure 3. A relationship between the $\mathrm{RBC}$ axial ratios and $\mathrm{SD}$ for the healthy controls, untreated diabetes and treated with DES and DEF was noted, and is illustrated in scatter plots (see Figure 4A and B).

\section{Scanning electron microscopy (SEM) of erythrocytes}

Figure 5 shows whole blood with added thrombin, which serves to create an extensive fibrin network around RBCs from a typical healthy individual. Figure 6 shows whole blood from diabetic patients before and after treatment where left, shows untreated WB, middle, shows WB treated with DFX and right, shows whole blood treated with DFO. Table 7 shows the detail of the diabetic patients shown in Figure 6. WB with added thrombin of healthy individuals forms a fibre net around

Table 7 Diabetic patient details of micrographs from the SEM analysis shown in Figure 6

\begin{tabular}{|c|c|c|c|c|c|c|}
\hline & Gender & Age & $\begin{array}{l}\text { Iron }\left(\mu \mathrm{mol} . \mathrm{L}^{-1}\right) \\
11.6-31.3\end{array}$ & $\begin{array}{l}\text { Transferrin } \\
\left(\mathrm{g} . \mathrm{L}^{-1}\right) \text { 2.2-3.7 }\end{array}$ & $\begin{array}{l}\text { \% saturation } \\
20-50 \%\end{array}$ & $\begin{array}{l}\text { Serum ferritin }\left(\mathrm{ng} \cdot \mathrm{mL}^{-1}\right) \\
M=20-250 \mathrm{~F}=10-120\end{array}$ \\
\hline DIABETES 29 & M & 72 & 25.3 & 2.4 & 42 & 386 \\
\hline DIABETES 44 & $\mathrm{~F}$ & 66 & 28.6 & 2.6 & 44 & 359 \\
\hline DIABETES 50 & M & 61 & 23 & 1.9 & 48 & 1097 \\
\hline DIABETES 45 & Yes & M & 60 & 18 & 2.4 & 88 \\
\hline DIABETES 46 & $\mathrm{~F}$ & 69 & 9.6 & 2.3 & 17 & 74 \\
\hline DIABETES 49 & $\mathrm{~F}$ & 62 & 12.4 & 2.2 & 23 & 58 \\
\hline
\end{tabular}


Table 8 Statistical analyses of membrane stiffness as measured by Young's modulus values of the diabetic group and treated groups

\begin{tabular}{llll}
\hline Group & Mean Young's modulus & SD & P-value \\
\hline Healthy individuals & 46710 & 39210 & - \\
Diabetes & 56483 & 64418 & $1.15 \mathrm{E}-13$ \\
Diabetes + DFX & 51238 & 58225 & $2.7 \mathrm{E}-06$ \\
Diabetes + DFO & 50446 & 36073 & $1.6 \mathrm{E}-10$ \\
\hline
\end{tabular}

(Diabetes $\mathrm{p}$-value is from a pairwise comparison with the healthy individual group. DFX and DFO diabetes-treated $p$-values are from pairwise comparisons with the diabetic group).

the typical discoid RBCs. The RBCs keep their characteristic shape. However, in the diabetic populations, the $\mathrm{RBC}$ structure is compromised and in all the samples, the RBCs twist and fold easily in the presence of the fibrin fibres In the presence of the 2 chelators, it seems as if the RBCs do regain their typical discoid shape. See middle and right column micrographs of Figure 6. SEM and LM axial ratio analyses both showed that RBC shapes are changed in untreated RBCs of diabetic individuals (left column), but that chelator treatment seems to stabilize RBC shape and membranes (middle and right columns) (also noted in the AFM results shown in later paragraphs).

\section{Atomic force microscopy of erythrocyte membranes}

A significant increase in the Young's modulus (stiffness) was seen in the RBCs of 22 randomly selected diabetic patients, whose blood was treated with the 2 chelators. This reflects a decrease in elasticity and an assumed altered functionality in these cells. Treatment with either DFX or DFO decreased the Young's modulus values towards more normal values, indicating a possible improvement in the elasticity of the cells (see Figure 7 and Table 8).

However, when the elasticity measurements are compared individually after treatment with the iron chelating agents a more complex picture emerges, due to the substantial variation in the two cohorts. Although on average the iron chelators caused a significant increase in elasticity, more than $50 \%$ of the diabetic group treated with DFX and almost $40 \%$ treated with DFO showed an increase in the elastic (see Figure 8).

\section{Scanning electron microscopy of fibrin network}

Figure 9 shows plasma with added thrombin to create an extensive fibrin network from a typical healthy individual. Figure 10 shows whole blood from diabetic patients before and after treatment, where column A shows untreated WB, column B shows WB treated with DFX and column $C$ shows WB treated with DFO. Smears were chosen that represents the sample, e.g. normal iron levels, increased iron levels and whether addition of chelators showed a significant P-value (or not); see Table 7 for specific details of the patients shown in the figure. Typically, fibrin forms individually visible fibres. However, in the presence of inflammation, the fibrin clots abnormally, to form finer fibres and in some cases, a continuous layer, where individual fibres

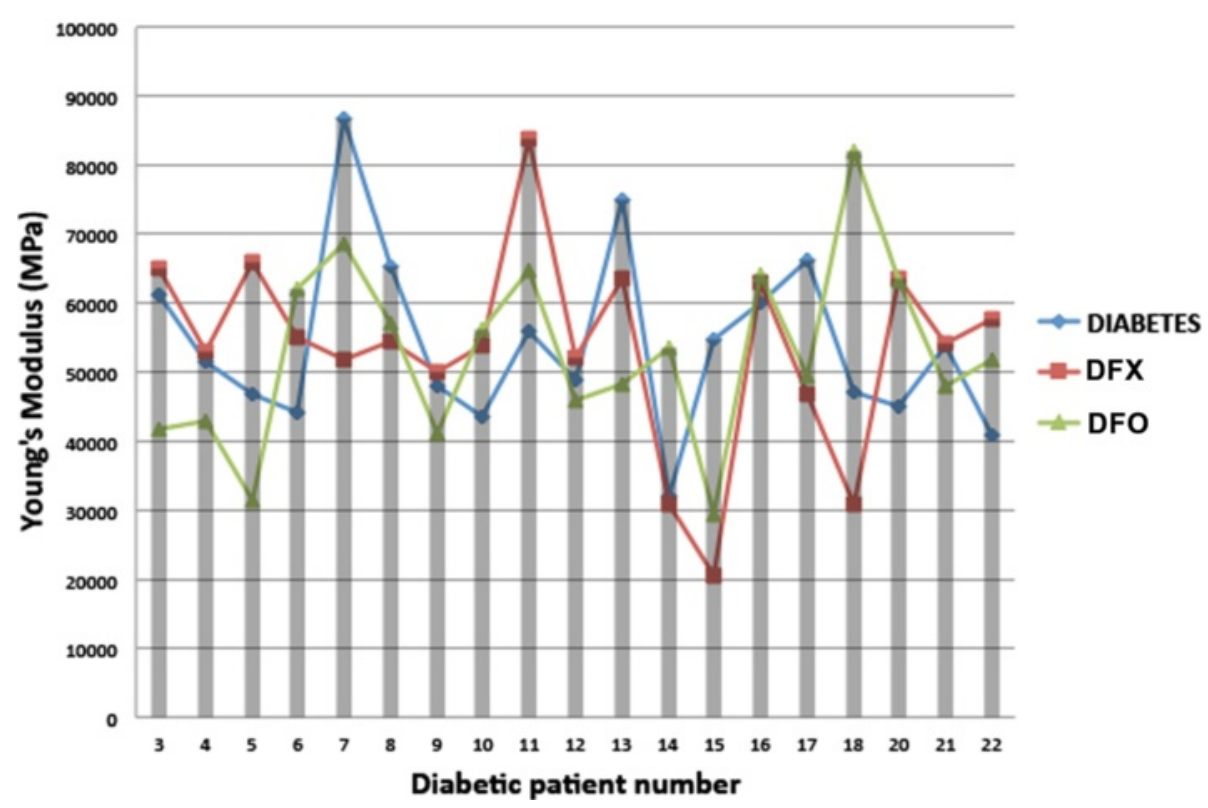

Figure 8 Young's modulus (stiffness) measurements to show trends in 19 of the individual diabetic erythrocytes after treatment with DFX and DFO. 


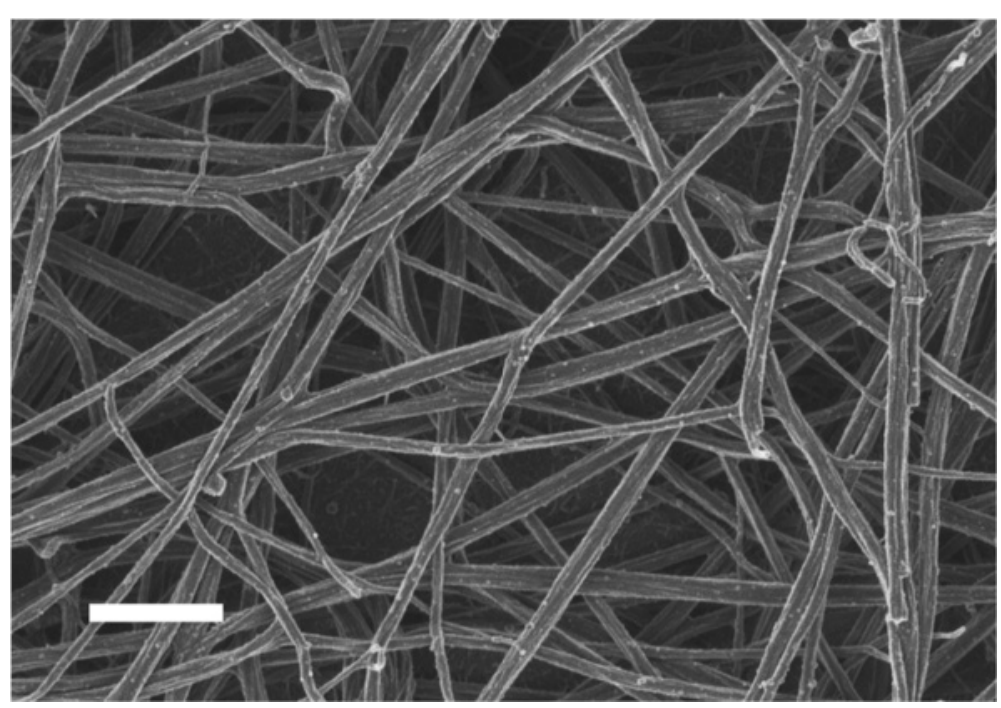

Figure 9 Plasma from a healthy individual, with added thrombin, to create an extensive fibrin network. Male: 58 ; serum ferritin: $208 \mathrm{ng}$. $\mathrm{mL}^{-1}$. Scale Bar $=1 \mu \mathrm{M}$.

are not visible. This has previously been noted in diabetic patients $[95,96]$. With the addition of the 2 chelators, fibrin nets with visible individual fibres are seen. This was found irrespective of increased SF levels (see Table 9) and we have argued [139] that serum ferritin - which not even exist as it is it not an extracellular iron transporter - is probably devoid of much iron anyway.

\section{Discussion}

Type II diabetes mellitus is a metabolic disorder of deranged fat, protein and carbohydrate metabolism resulting in hyperglycaemia from insulin resistance and inadequate insulin secretion [152]. This condition is very difficult to treat and even in countries like the USA, fewer than $50 \%$ of patients achieve the HbA1c goal of < $7 \%$ set by the American Diabetes Association [152,153]. One of the reasons might be poor adherence to treatment regimes [154-156], as well as poor diet and knowledge regarding nutrition [157].

In the current work, we noted a changed RBC shape and membrane structure, as well as a matted fibrin fibre structure. Previously, we suggested that this might be due to oxidative stress and increased iron levels [93]. Oxidative stress in diabetic subjects, including those with cardiovascular manifestations, may also be attributed to the hyperglycaemia which modifies the RBC membrane dynamic and electrokinetic properties when compared to healthy controls [158].

In the present study, we noted that the axial ratio of the RBCs from diabetic patients was significantly greater than that of matched controls, as seems to occur in a variety of inflammatory diseases [140,143,159]. Iron dysregulation is often intimately involved and unliganded iron can act in one of two main ways, viz simply by electrostatics or via its ability to catalyse hydroxyl radical formation with covalent modification (by hydroxyl radicals) of proteins and other macromolecules $[139,141,160]$. The former, but not the latter, may be reversed by iron chelators [139]. In the present study, the chelators had no effect on the axial ratios, consistent with the view that in the chronic conditions of diabetes the changes are mainly due to hydroxyl radical formation. However, the chelators did have effects on the detailed morphology of the RBCs, suggesting some contribution of electrostatic forces. AFM measurements indicated that the membrane stiffness of the RBCs of diabetics was significantly greater than that of controls, and that overall this could be alleviated by the addition of iron chelators. However, a detailed analysis showed that this was quite patient-specific.

Recently, Berndt-Zipfel and coworkers, showed that RBC deformability (measured using a laser-assisted optical rotational cell analyzer by determining the elongation index) was also changed in type II diabetes, and that an improved RBC deformability correlate of improved glycaemic control [105]. The current patient sample mostly had very poor glycaemic control, and this might partly be the reason for limited RBC shape and deformability improvement.

In a similar vein, the ultrastructure of the fibrin clots formed in the blood of diabetic patients following 

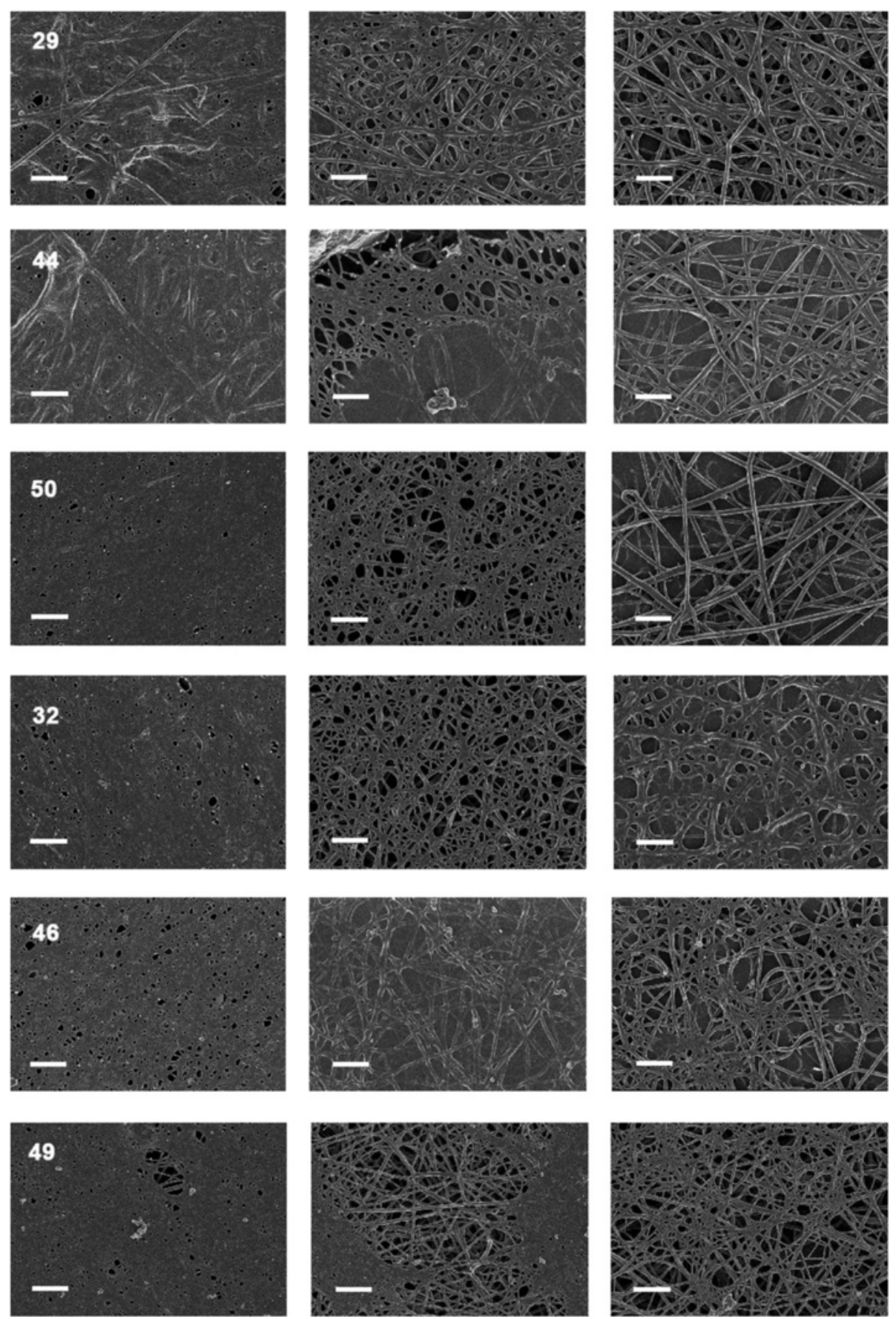

Figure 10 Fibrin formed in plasma from diabetic patients before and after treatment. Left: untreated; middle: Deferasirox (DFX) and right: desferrioxamine (DFO).

thrombin addition in vitro were highly aberrant in nature relative to those from the controls, much as we have seen before in a variety of inflammatory diseases. In this study, the chelators could act to make the fibrin morphology much more like those of the controls, consistent with the view that at least of these effects were due to the presence of unliganded iron acting electrostatically to modify fibrinogen and its behavior during polymerization to form fibrin.

Overall, we note, as we have before in a number of inflammatory diseases $[139,141,143,159,160]$ that patients with type II diabetes manifest this via significant 
Table 9 Diabetic patient details of micrographs from the SEM analysis shown in Figure 10

\begin{tabular}{|c|c|c|c|c|c|c|}
\hline & Gender & Age & $\begin{array}{l}\text { Iron }\left(\mu \mathrm{mol} . \mathrm{L}^{-1}\right) \\
11.6-31.3\end{array}$ & $\begin{array}{l}\text { Transferrin } \\
\left(\mathrm{g} . \mathrm{L}^{-1}\right) \text { 2.2-3.7 }\end{array}$ & $\begin{array}{l}\% \text { saturation } \\
20-50 \%\end{array}$ & $\begin{array}{l}\left.\text { Serum ferritin (ng. } \mathrm{mL}^{-1}\right) \\
\mathrm{M}=20-250 \mathrm{~F}=10-120\end{array}$ \\
\hline DIABETES 29 & M & 72 & 25.3 & 2.4 & 42 & 386 \\
\hline DIABETES 44 & $\mathrm{~F}$ & 66 & 28.6 & 2.6 & 44 & 359 \\
\hline DIABETES 50 & M & 61 & 23 & 1.9 & 48 & 1097 \\
\hline DIABETES 32 & M & 55 & 10.3 & 2.2 & 19 & 88 \\
\hline DIABETES 46 & $\mathrm{~F}$ & 69 & 9.6 & 2.3 & 17 & 74 \\
\hline DIABETES 49 & $\mathrm{~F}$ & 62 & 12.4 & 2.2 & 23 & 58 \\
\hline
\end{tabular}

Bold values are above and italic values below the reference (normal) range.

changes in both the morphology of their erythrocytes and in the nature of the fibrin fibres formed upon the addition of thrombin. We do not yet know whether these morphological changes have prognostic (as well as diagnostic) significance, but it is clear that lowering the amounts of labile iron are likely to be of benefit, as serum ferritin is an important disease marker, and implicated in most inflammatory conditions. Previously, we argued that and it is mainly a leakage product from damaged cells [139]. There are therefore possible clinical implications for "labile" (chelatable) iron in the thrombin-elicited fibrin formation in the plasma of diabetic patients, and also the elasticity of RBCs, possibly associated with serum proteins.

\section{Competing interests}

The authors declare that they have no competing interests.

\section{Authors' contributions}

EP: sample analysis, writing of manuscript. JB and NV: sample preparation. SA: AFM analysis. PS: medical practitioner who collected samples, clinical perspective. AVB: AFM analysis. DBK: writing and editing of manuscript. All authors read and approved the final manuscript.

\section{Acknowledgements}

We thank the Biotechnology and Biological Sciences Research Council (grant BB/L025752/1) as well as the National Research Foundation (NRF) of South Africa for supporting this collaboration.

\section{Author details}

'Department of Physiology, Faculty of Health Sciences, University of Pretoria, Private Bag x323, Arcadia 0007, South Africa. ${ }^{2}$ Unit of Microscopy and Microanalysis, University of Pretoria, Pretoria, South Africa. ${ }^{3}$ School of Chemistry and The Manchester Institute of Biotechnology, The University of Manchester, 131, Princess Street, Manchester M1 7DN, Lancs, UK.

Received: 12 January 2015 Accepted: 6 February 2015

Published online: 08 March 2015

\section{References}

1. Yang SH, Dou KF, Song WJ. Prevalence of diabetes among men and women in China. N Engl J Med. 2010;362(25):2425-6. author reply 2426.

2. Sattar N. Advances in managing type 2 diabetes: challenging old paradigms and developing new ones. F1000Prime Rep. 2014:6:42.

3. Moreira GC, Cipullo JP, Ciorlia LA, Cesarino CB, Vilela-Martin JF. Prevalence of Metabolic Syndrome: Association with Risk Factors and Cardiovascular Complications in an Urban Population. PLoS One. 2014;9(9):e105056.
4. Chevreul K, Berg Brigham K, Bouche C. The burden and treatment of diabetes in France. Global Health. 2014;10:6.

5. Rathmann W, Giani G. Global prevalence of diabetes: estimates for the year 2000 and projections for 2030. Diabetes Care. 2004:27(10):2568-9. author reply 2569 .

6. Zhang L, Zhang Z, Zhang Y, Hu G, Chen L. Evaluation of Finnish diabetes risk score in screening undiagnosed diabetes and prediabetes among U.S. Adults by gender and race: NHANES 1999-2010. PLoS One. 2014;9(5):e97865.

7. Monnier L, Hanefeld M, Schnell O, Colette C, Owens D. Insulin and atherosclerosis: how are they related? Diabetes Metab. 2013;39(2):111-7.

8. Bays HE. Lowering low-density lipoprotein cholesterol levels in patients with type 2 diabetes mellitus. Int J Gen Med. 2014;7:355-64

9. Lorber D. Importance of cardiovascular disease risk management in patients with type 2 diabetes mellitus. Diab Metab Syndr Obes. 2014;7:169-83.

10. Klop B, Elte JW, Cabezas MC. Dyslipidemia in obesity: mechanisms and potential targets. Nutrients. 2013;5(4):1218-40.

11. Chehade JM, Gladysz M, Mooradian AD. Dyslipidemia in type 2 diabetes: prevalence, pathophysiology, and management. Drugs. 2013;73(4):327-39.

12. Martín-Timón I, Sevillano-Collantes C, Segura-Galindo A, Cañizo-Gómez FJ. Type 2 diabetes and cardiovascular disease: have all risk factors the same strength? World J Diabetes. 2014;5(4):444-70.

13. Meusel LA, Kansal N, Tchistiakova E, Yuen W, Maclntosh BJ, Greenwood CE, et al. A systematic review of type 2 diabetes mellitus and hypertension in imaging studies of cognitive aging: time to establish new norms. Front Aging Neurosci. 2014;6:148

14. Rhee EP, Cheng S, Larson MG, Walford GA, Lewis GD, McCabe E, et al. Lipid profiling identifies a triacylglycerol signature of insulin resistance and improves diabetes prediction in humans. J Clin Invest. 2011:121(4):1402-11.

15. Anderson SG, Dunn WB, Banerjee M, Brown M, Broadhurst DI, Goodacre R, et al. Evidence that multiple defects in lipid regulation occur before hyperglycemia during the prodrome of type-2 diabetes. PLoS One. 2014;9(9):e103217.

16. Meikle PJ, Wong G, Barlow CK, Kingwell BA. Lipidomics: potential role in risk prediction and therapeutic monitoring for diabetes and cardiovascular disease. Pharmacol Ther. 2014;143(1):12-23.

17. Wong G, Barlow CK, Weir JM, Jowett JB, Magliano DJ, Zimmet P, et al. Inclusion of plasma lipid species improves classification of individuals at risk of type 2 diabetes. PLoS One. 2013;8(10):e76577.

18. Moreno G, Mangione CM. Management of cardiovascular disease risk factors in older adults with type 2 diabetes mellitus: 2002-2012 literature review. J Am Geriatr Soc. 2013;61(11):2027-37.

19. Green JB. Understanding the type 2 diabetes mellitus and cardiovascular disease risk paradox. Postgrad Med. 2014;126(3):190-204.

20. Aronson D, Edelman ER. Coronary artery disease and diabetes mellitus. Cardiol Clin. 2014;32(3):439-55.

21. Schwab U, Lauritzen L, Tholstrup T, Haldorssoni T, Riserus U, Uusitupa M, et al. Effect of the amount and type of dietary fat on cardiometabolic risk factors and risk of developing type 2 diabetes, cardiovascular diseases, and cancer: a systematic review. Food Nutr Res. 2014;10:58.

22. Bloomgarden ZT. Consequences of diabetes: cardiovascular disease. Diabetes Care. 2004;27(7):1825-31.

23. Stolar MW, Chilton RJ. Type 2 diabetes, cardiovascular risk, and the link to insulin resistance. Clin Ther. 2003;25(Suppl B):B4-31. 
24. Panguluri SK, Tur J, Chapalamadugu KC, Katnik C, Cuevas J, Tipparaju SM. MicroRNA-301a mediated regulation of Kv4.2 in diabetes: identification of key modulators. PLoS One. 2013;8(4):e60545.

25. Mandosi E, Fallarino M, Gatti A, Carnovale A, Rossetti M, Lococo E, et al. Atorvastatin downregulates monocyte CD36 expression, nuclear NFkappaB and TNFalpha levels in type 2 diabetes. J Atheroscler Thromb. 2010;17(6):539-45.

26. Grove EL, Gregersen S. Antiplatelet therapy in patients with diabetes mellitus. Curr Vasc Pharmacol. 2012;10(4):494-505.

27. Hotamisligil GS. Inflammation and metabolic disorders. Nature. 2006;444 (7121):860-7.

28. Andreasen AS, Kelly M, Berg RM, Moller K, Pedersen BK. Type 2 diabetes is associated with altered NF-kappaB DNA binding activity, JNK phosphorylation, and AMPK phosphorylation in skeletal muscle after LPS. PLoS One. 2011;6(9):e23999.

29. Pickup JC. Inflammation and activated innate immunity in the pathogenesis of type 2 diabetes. Diabetes Care. 2004;27(3):813-23.

30. Galaris D, Pantopoulos K. Oxidative stress and iron homeostasis: mechanistic and health aspects. Crit Rev Clin Lab Sci. 2008;45(1):1-23.

31. Jomova K, Valko M. Advances in metal-induced oxidative stress and human disease. Toxicology. 2011;283(2-3):65-87.

32. Jomova K, Valko M. Importance of iron chelation in free radical-induced oxidative stress and human disease. Curr Pharm Des. 2011;17(31):3460-73.

33. Kell DB. Iron behaving badly: inappropriate iron chelation as a major contributor to the aetiology of vascular and other progressive inflammatory and degenerative diseases. BMC Med Genomics. 2009;2:2.

34. Kell DB. Towards a unifying, systems biology understanding of large-scale cellular death and destruction caused by poorly liganded iron: Parkinson's, Huntington's, Alzheimer's, prions, bactericides, chemical toxicology and others as examples. Arch Toxicol. 2010;84(11):825-89.

35. Rochette L, Zeller M, Cottin Y, Vergely C. Diabetes, oxidative stress and therapeutic strategies. Biochim Biophys Acta. 2014;1840(9):2709-29.

36. Kim HK, Kim JE, Park SH, Kim YI, Nam-Goong IS, Kim ES. High coagulation factor levels and low protein $\mathrm{C}$ levels contribute to enhanced thrombin generation in patients with diabetes who do not have macrovascular complications. J Diabetes Complications. 2014;28(3):365-9.

37. Madan R, Gupt B, Saluja S, Kansra UC, Tripathi BK, Guliani BP. Coagulation profile in diabetes and its association with diabetic microvascular complications. J Assoc Physicians India. 2010;58:481-4.

38. Samad F, Ruf W. Inflammation, obesity, and thrombosis. Blood. 2013;122(20):3415-22.

39. Cortez-Cooper M, Meaders E, Stallings J, Haddow S, Kraj B, Sloan G, et al. Soluble TNF and IL-6 receptors: Indicators of vascular health in women without cardiovascular disease. Vasc Med (London, England). 2013;18(5):282-9.

40. Jialal I, Huet BA, Kaur H, Chien A, Devaraj S. Increased toll-like receptor activity in patients with metabolic syndrome. Diabetes Care. 2012;35(4):900-4

41. Baune BT, Rothermundt M, Ladwig KH, Meisinger C, Berger K. Systemic inflammation (Interleukin 6) predicts all-cause mortality in men: results from a 9-year follow-up of the MEMO Study. Age (Dordr). 2011;33(2):209-17.

42. Kitada M, Zhang Z, Mima A, King GL. Molecular mechanisms of diabetic vascular complications. J Diabetes Investig. 2010;1(3):77-89.

43. Cucuianu M, Coca M. Thrombotic tendency in diabetes mellitus. Revisiting and revising a study initiated 30 years ago. Rom J Intern Med. 2012;50(2):107-15.

44. Goldberg RB. Cytokine and cytokine-like inflammation markers, endothelial dysfunction, and imbalanced coagulation in development of diabetes and its complications. J Clin Endocrinol Metab. 2009;94(9):3171-82.

45. Tousoulis D, Papageorgiou N, Androulakis E, Siasos G, Latsios G, Tentolouris K, et al. Diabetes mellitus-associated vascular impairment: novel circulating biomarkers and therapeutic approaches. J Am Coll Cardiol. 2013;62(8):667-76.

46. Khanna S, Singh GB, Khullar M. Nitric oxide synthases and diabetic cardiomyopathy. Nitric Oxide. 2014;43:29-34

47. Dellamea BS, Leitão CB, Friedman R, Canani LH. Nitric oxide system and diabetic nephropathy. Diabetol Metab Syndr. 2014;6(1):17.

48. Dzugkoev SG, Metel'skaya VA, Dzugkoeva FS. Effects of endogenous regulators of endothelial NO synthase on nitric oxide homeostasis and blood serum lipoproteins during experimental diabetes mellitus. Bull Exp Biol Med. 2013;156(2):205-8.

49. Schneider MP, Ott C, Schmidt S, Kistner I, Friedrich S, Schmieder RE. Poor glycemic control is related to increased nitric oxide activity within the renal circulation of patients with type 2 diabetes. Diabetes Care. 2013;36(12):4071-5.

50. Cohen RA, Tong X. Vascular oxidative stress: the common link in hypertensive and diabetic vascular disease. J Cardiovasc Pharmacol. 2010;55(4):308-16.

51. Prasad P, Tiwari AK, Kumar KM, Ammini AC, Gupta A, Gupta R, et al. Association of TGFbeta1, TNFalpha, CCR2 and CCR5 gene polymorphisms in type-2 diabetes and renal insufficiency among Asian Indians. BMC Med Genet. 2007:8:20

52. Chacón MR, Vendrell J, Miranda M, Ceperuelo-Mallafré V, Megía A, Gutiérrrez $C$, et al. Different TNFalpha expression elicited by glucose in monocytes from type 2 diabetes mellitus patients. Atherosclerosis. 2007;194(2):e18-25.

53. Kampoli AM, Tousoulis D, Briasoulis A, Latsios G, Papageorgiou N, Stefanadis C. Potential pathogenic inflammatory mechanisms of endothelial dysfunction induced by type 2 diabetes mellitus. Curr Pharm Des. 2011;17(37):4147-58.

54. Moraes PA, Yonamine CY, Pinto Junior DC, Esteves JV, Machado UF, Mori RC. Insulin acutely triggers transcription of SIc2a4 gene: participation of the AT-rich, E-box and NFKB-binding sites. Life Sci. 2014;114(1):36-44.

55. Kassan M, Choi SK, Galan M, Trebak M, Belmadani S, Matrougui K. Nuclear factor kappa B inhibition improves conductance artery function in type 2 diabetic mice. Diabetes Metab Res Rev. 2015;31(1):39-49. doi:10.1002/dmrr.2542

56. Patel S, Santani D. Role of NF-kappa B in the pathogenesis of diabetes and its associated complications. Pharmacol Rep. 2009;61(4):595-603.

57. Kassan M, Choi SK, Galan M, Bishop A, Umezawa K, Trebak M, et al. Enhanced NF-kappaB activity impairs vascular function through PARP-1-, SP-1-, and COX-2-dependent mechanisms in type 2 diabetes. Diabetes. 2013;62(6):2078-87.

58. Wong WT, Tian XY, Huang Y. Endothelial dysfunction in diabetes and hypertension: cross talk in RAS, BMP4, and ROS-dependent COX-2-derived prostanoids. J Cardiovasc Pharmacol. 2013;61(3):204-14.

59. Rudock ME, Liu Y, Ziegler JT, Allen SG, Lehtinen AB, Freedman Bl, et al. Association of polymorphisms in cyclooxygenase (COX)-2 with coronary and carotid calcium in the Diabetes Heart Study. Atherosclerosis. 2009;203(2):459-65.

60. Kellogg AP, Cheng HT, Pop-Busui R. Cyclooxygenase-2 pathway as a potential therapeutic target in diabetic peripheral neuropathy. Curr Drug Targets. 2008;9(1):68-76.

61. Bagi Z, Erdei N, Papp Z, Edes I, Koller A. Up-regulation of vascular cyclooxygenase-2 in diabetes mellitus. Pharmacol Rep. 2006;58(Suppl):52-6.

62. Schoenberger SD, Kim SJ, Sheng J, Rezaei KA, Lalezary M, Cherney E. Increased prostaglandin E2 (PGE2) levels in proliferative diabetic retinopathy, and correlation with VEGF and inflammatory cytokines. Invest Ophthalmol Vis Sci. 2012;53(9):5906-11.

63. Salvi GE, Beck JD, Offenbacher S. PGE2, IL-1 beta, and TNF-alpha responses in diabetics as modifiers of periodontal disease expression. Ann Periodontol. 1998;3(1):40-50

64. Salonen JT, Tuomainen TP, Nyyssonen K, Lakka HM, Punnonen K. Relation between iron stores and non-insulin dependent diabetes in men: case-control study. BMJ. 1998;317(7160):727.

65. Ford ES, Cogswell ME. Diabetes and serum ferritin concentration among U. S. adults. Diabetes Care. 1999;22(12):1978-83.

66. Wilson JG, Lindquist JH, Grambow SC, Crook ED, Maher JF. Potential role of increased iron stores in diabetes. Am J Med Sci. 2003;325(6):332-9.

67. Jiang R, Manson JE, Meigs JB, Ma J, Rifai N, Hu FB. Body iron stores in relation to risk of type 2 diabetes in apparently healthy women. JAMA 2004;291(6):711-7.

68. Mert M, Korkmaz M, Temizel M, Acar M. The level of ferritin in diabetic and nondiabetic patients with acute myocardial infarction. Turk J Med Sci. 2005:35:25-34.

69. Acton RT, Barton JC, Passmore LV, Adams PC, Speechley MR, Dawkins FW, et al. Relationships of serum ferritin, transferrin saturation, and HFE mutations and self-reported diabetes in the Hemochromatosis and Iron Overload Screening (HEIRS) study. Diabetes Care. 2006;29(9):2084-9.

70. Alissa EM, Ahmed WH, Al-Ama N, Ferns GA. Relationship between indices of iron status and coronary risk factors including diabetes and the metabolic syndrome in Saudi subjects without overt coronary disease. J Trace Elem Med Biol. 2007;21(4):242-54.

71. Forouhi NG, Harding AH, Allison M, Sandhu MS, Welch A, Luben R, et al. Elevated serum ferritin levels predict new-onset type 2 diabetes: results from the EPIC-Norfolk prospective study. Diabetologia. 2007;50(5):949-56. 
72. Jehn ML, Guallar E, Clark JM, Couper D, Duncan BB, Ballantyne CM, et al. A prospective study of plasma ferritin level and incident diabetes: the Atherosclerosis Risk in Communities (ARIC) Study. Am J Epidemiol. 2007;165(9):1047-54

73. Sun L, Franco OH, Hu FB, Cai L, Yu Z, Li H, et al. Ferritin concentrations, metabolic syndrome, and type 2 diabetes in middle-aged and elderly chinese. J Clin Endocrinol Metab. 2008;93(12):4690-6.

74. Kolberg JA, Jørgensen T, Gerwien RW, Hamren S, McKenna MP, Moler E, et al. Development of a type 2 diabetes risk model from a panel of serum biomarkers from the Inter99 cohort. Diabetes Care. 2009;32(7):1207-12.

75. Rajpathak SN, Crandall JP, Wylie-Rosett J, Kabat GC, Rohan TE, Hu FB. The role of iron in type 2 diabetes in humans. Biochim Biophys Acta. 2009;1790:671-81.

76. Kim CH, Kim HK, Bae SJ, Park JY, Lee KU. Association of elevated serum ferritin concentration with insulin resistance and impaired glucose metabolism in Korean men and women. Metabolism. 2011;60(3):414-20.

77. Lee BK, Kim Y, Kim Yl. Association of serum ferritin with metabolic syndrome and diabetes mellitus in the South Korean general population according to the Korean National Health and Nutrition Examination Survey 2008. Metabolism. 2011;60(10):1416-24.

78. Ryoo JH, Kim MG, Lee DW, Shin JY. The relationship between serum ferritin and metabolic syndrome in healthy Korean men. Diabetes Metab Res Rev. 2011;27(6):597-603.

79. Bao W, Rong Y, Rong S, Liu L. Dietary iron intake, body iron stores, and the risk of type 2 diabetes: a systematic review and meta-analysis. BMC Med. 2012;10:119.

80. Lyssenko V, Jørgensen T, Gerwien RW, Hansen T, Rowe MW, McKenna MP, et al. Validation of a multi-marker model for the prediction of incident type 2 diabetes mellitus: combined results of the Inter99 and Botnia studies. Diab Vasc Dis Res. 2012;9(1):59-67.

81. Montonen J, Boeing $H$, Steffen A, Lehmann R, Fritsche A, Joost HG, et al. Body iron stores and risk of type 2 diabetes: results from the European Prospective Investigation into Cancer and Nutrition (EPIC)-Potsdam study. Diabetologia. 2012;55(10):2613-21.

82. Zhao Z, Li S, Liu G, Yan F, Ma X, Huang Z, et al. Body iron stores and hemeiron intake in relation to risk of type 2 diabetes: a systematic review and meta-analysis. PLoS One. 2012;7(7):e41641.

83. Aregbesola AO, Voutilainen S, Virtanen JK, Mursu J, Tuomainen TP. Body iron stores and the risk of type 2 diabetes in middle-aged Men. Eur J Endocrinol. 2013;169(2):247-53.

84. Guo X, Zhou D, An P, Wu Q, Wang H, Wu A, et al. Associations between serum hepcidin, ferritin and $\mathrm{Hb}$ concentrations and type 2 diabetes risks in a Han Chinese population. Br J Nutr. 2013;110(12):2180-5

85. Jung $\mathrm{CH}$, Lee $\mathrm{MJ}$, Hwang JY, Jang JE, Leem J, Park JY, et al. Elevated serum ferritin level is associated with the incident type 2 diabetes in healthy korean men: a 4 year longitudinal study. PLoS One. 2013;8(9):e75250.

86. Kundu D, Roy A, Mandal T, Bandyopadhyay U, Ghosh E, Ray D. Relation of iron stores to oxidative stress in type 2 diabetes. Niger J Clin Pract. 2013;16(1):100-3

87. Kunutsor SK, Apekey TA, Walley J, Kain K. Ferritin levels and risk of type 2 diabetes mellitus: an updated systematic review and meta-analysis of prospective evidence. Diabetes Metab Res Rev. 2013;29(4):308-18.

88. Ponikowska B, Suchocki T, Paleczny B, Olesinska M, Powierza S, BorodulinNadzieja L, et al. Iron status and survival in diabetic patients with coronary artery disease. Diabetes Care. 2013;36(12):4147-56.

89. White $\mathrm{DL}$, Collinson A. Red meat, dietary heme iron, and risk of type 2 diabetes: the involvement of advanced lipoxidation endproducts. Adv Nutr. 2013:4(4):403-11.

90. Wang X, Bao W, Liu J, Ouyang YY, Wang D, Rong S, et al. Inflammatory markers and risk of type 2 diabetes: a systematic review and meta-analysis. Diabetes Care. 2013;36(1):166-75.

91. Zuccollo A, Shi C, Mastroianni R, Maitland-Toolan KA, Weisbrod RM, Zang M, et al. The thromboxane A2 receptor antagonist $\$ 18886$ prevents enhanced atherogenesis caused by diabetes mellitus. Circulation. 2005;112(19):3001-8.

92. Winocour PD. Platelets, vascular disease, and diabetes mellitus. Can J Physiol Pharmacol. 1994;72(3):295-303.

93. Buys AV, Van Rooy MJ, Soma P, Van Papendorp D, Lipinski B, Pretorius E. Changes in red blood cell membrane structure in type 2 diabetes: a scanning electron and atomic force microscopy study. Cardiovasc Diabetol. 2013;12(1):25.

94. Pretorius E, Lipinski B. Iron alters red blood cell morphology. Blood. 2013;121(1):9
95. Pretorius E, Oberholzer HM, van der Spuy WJ, Swanepoel AC, Soma P. Qualitative scanning electron microscopy analysis of fibrin networks and platelet abnormalities in diabetes. Blood Coagul Fibrinolysis. 2011;22(6):463-7.

96. Pretorius E, Lipinski B, Bester J, Vermeulen N, Soma P. Albumin stabilizes fibrin fiber ultrastructure in low serum albumin type 2 diabetes. Ultrastruct Pathol. 2013;37(4):254-7.

97. Bochenek M, Zalewski J, Sadowski J, Undas A. Type 2 diabetes as a modifier of fibrin clot properties in patients with coronary artery disease. J Thromb Thrombolysis. 2013;35(2):264-70.

98. Dunn EJ, Philippou H, Ariëns RA, Grant PJ. Molecular mechanisms involved in the resistance of fibrin to clot lysis by plasmin in subjects with type 2 diabetes mellitus. Diabetologia. 2006;49(5):1071-80.

99. Jin $H$, Xing $X$, Zhao H, Chen Y, Huang X, Ma S, et al. Detection of erythrocytes influenced by aging and type 2 diabetes using atomic force microscope. Biochem Biophys Res Commun. 2010;391(4):1698-702.

100. Forsyth AM, Braunmuller S, Wan J, Franke T, Stone HA. The effects of membrane cholesterol and simvastatin on red blood cell deformability and ATP release. Microvasc Res. 2012;83(3):347-51.

101. Koter M, Franiak I, Broncel M, Chojnowska-Jezierska J. Effects of simvastatin and pravastatin on peroxidation of erythrocyte plasma membrane lipids in patients with type 2 hypercholesterolemia. Can J Physiol Pharmacol. 2003;81(5):485-92.

102. Piagnerelli M, Zouaoui Boudjeltia K, Brohee D, Vereerstraeten A, Piro P, Vincent $J$, et al. Assessment of erythrocyte shape by flow cytometry techniques. J Clin Pathol. 2007:60(5):549-54.

103. Baskurt OK, Meiselman HJ. Erythrocyte aggregation: basic aspects and clinical importance. Clin Hemorheol Microcirc. 2013;53(1-2):23-37.

104. Engström G, Smith JG, Persson M, Nilsson PM, Melander O, Hedblad B. Red cell distribution width, haemoglobin A1c and incidence of diabetes mellitus. J Intern Med. 2014;276(2):174-83.

105. Berndt-Zipfel C, Michelson G, Dworak M, Mitry M, Loffler A, Pfützner A, et al. Vildagliptin in addition to metformin improves retinal blood flow and erythrocyte deformability in patients with type 2 diabetes mellitus - results from an exploratory study. Cardiovasc Diabetol. 2013;12:59.

106. Lipinski B, Pretorius E. Novel pathway of ironinduced blood coagulation: implications for diabetes mellitus and its complications. Pol Arch Med Wewn. 2012;122(3):115-22.

107. Pretorius E. The adaptability of red blood cells. Cardiovasc Diabetol. 2013;12:63.

108. Konieczynska M, Fil K, Bazanek M, Undas A. Prolonged duration of type 2 diabetes is associated with increased thrombin generation, prothrombotic fibrin clot phenotype and impaired fibrinolysis. Thromb Haemost. 2014;111(4):685-93.

109. Undas A, Kaczmarek P, Sladek K, Stepien E, Skucha W, Rzeszutko M, et al. Fibrin clot properties are altered in patients with chronic obstructive pulmonary disease. Beneficial effects of simvastatin treatment. Thromb Haemost. 2009;102(6):1176-82.

110. Undas A, Topor-Madry R, Tracz W. Simvastatin increases clot permeability and susceptibility to lysis in patients with LDL cholesterol below $3.4 \mathrm{mmol} / \mathrm{l}$. Pol Arch Med Wewn. 2009;119(6):354-9.

111. Undas A, Celinska-Lowenhoff M, Lowenhoff T, Szczeklik A. Statins, fenofibrate, and quinapril increase clot permeability and enhance fibrinolysis in patients with coronary artery disease. J Thromb Haemost. 2006;4(5):1029-36.

112. Haslinger B, Goedde MF, Toet KH, Kooistra T. Simvastatin increases fibrinolytic activity in human peritoneal mesothelial cells independent of cholesterol lowering. Kidney Int. 2002;62(5):1611-9.

113. Undas A, Brummel KE, Musial J, Mann KG, Szczeklik A. Simvastatin depresses blood clotting by inhibiting activation of prothrombin, factor $\mathrm{V}$, and factor XII and by enhancing factor Va inactivation. Circulation. 2001;103(18):2248-53.

114. Mikashinovich Zl, Belousova ES. Analysis of biochemical changes in rat erythrocytes induced by long-term simvastatin treatment. Bull Exp Biol Med. 2013;155(5):628-30.

115. Rabini RA, Polenta M, Staffolani R, Tocchini M, Signore R, Testa I, et al. Effect of hydroxymethylglutaryl-CoA reductase inhibitors on the functional properties of erythrocyte membranes. Exp Mol Pathol. 1993;59(1):51-7.

116. Broncel M, Bala A, Koter-Michalak M, Duchnowicz P, Wojsznis W, Chojnowska-Jezierska J. Physicochemical modifications induced by statins therapy on human erythrocytes membranes. Wiad Lek (Warsaw, Poland 1960). 2007;60(7-8):321-8.

117. Clapp KM, Ellsworth ML, Sprague RS, Stephenson AH. Simvastatin and GGTI2133, a geranylgeranyl transferase inhibitor, increase erythrocyte 
deformability but reduce low $\mathrm{O}(2)$ tension-induced ATP release. Am J Physiol Heart Circ Physiol. 2013;304(5):H660-6.

118. Uydu HA, Yildirmis S, Orem C, Calapoglu M, Alver A, Kural B, et al. The effects of atorvastatin therapy on rheological characteristics of erythrocyte membrane, serum lipid profile and oxidative status in patients with dyslipidemia. J Membr Biol. 2012;245(11):697-705.

119. Grant PJ. Beneficial effects of metformin on haemostasis and vascular function in man. Diabetes Metab. 2003;29(4 Pt 2):6s44-52.

120. Standeven KF, Ariëns RA, Whitaker P, Ashcroft AE, Weisel JW, Grant PJ. The effect of dimethylbiguanide on thrombin activity, FXIII activation, fibrin polymerization, and fibrin clot formation. Diabetes. 2002;51(1):189-97.

121. Nair CH, Azhar A, Wilson JD, Dhall DP. Studies on fibrin network structure in human plasma. Part II-Clinical application: diabetes and antidiabetic drugs. Thromb Res. 1991;64(4):477-85.

122. Sobel BE, Hardison RM, Genuth S, Brooks MM, McBane 3rd RD, Schneider DJ, et al. Profibrinolytic, antithrombotic, and antiinflammatory effects of an insulinsensitizing strategy in patients in the Bypass Angioplasty Revascularization Investigation 2 Diabetes (BARI 2D) trial. Circulation. 2011;124(6):695-703.

123. González Maqueda I. Adrenoreceptors, endothelial function, and lipid profile: effects of atenolol, doxazosin, and carvedilol. Coron Artery Dis. 1994:5(11):909-18.

124. Habon T, Szabados E, Kesmarky G, Halmosi R, Past T, Sumegi B, et al. The effect of carvedilol on enhanced ADP-ribosylation and red blood cell membrane damage caused by free radicals. Cardiovasc Res. 2001;52(1):153-60.

125. Kowalski J, Banach M, Barylski M, Irzmanski R, Pawlicki L. Carvedilol modifies antioxidant status of patients with stable angina. Cell Mol Biol Lett. 2008;13(2):230-9.

126. Bolli R, Ware JA, Brandon TA, Weilbaecher DG, Mace Jr ML. Plateletmediated thrombosis in stenosed canine coronary arteries: inhibition by nicergoline, a platelet-active alpha-adrenergic antagonist. J Am Coll Cardiol. 1984;3(6):1417-26.

127. Tiryaki O, Buyukhatipoglu H, Usalan C. Plasma plasminogen activator inhibitor 1 (PAI-1) and P-selectin levels in urgent hypertension: effect of single dose captopril and nifedipine on fibrinolytic activity. Clin Exp Hypertens (New York 1993). 2010;32(6):347-51.

128. Taylor JE, Belch JJ, McLaren M, Stewart WK. Effect of nifedipine on changes in fibrinogen and von Willebrand factor in haemodialysis patients treated with recombinant human erythropoietin. Blood Coagul Fibrinolysis. 1995;6(2):100-4.

129. Knapp M, Lisowska A, Knapp P, Baranowski M. Dose-dependent effect of aspirin on the level of sphingolipids in human blood. Adv Med Sci. 2013;58(2):274-81.

130. Manolis AS, Manolis TA, Papadimitriou P, Koulouris S, Melita H. Combined antiplatelet therapy: still a sweeping combination in cardiology. Cardiovasc Hematol Agents Med Chem. 2013;11(2):136-67.

131. Mehta SR. Aspirin for prevention and treatment of cardiovascular disease. Ann Intern Med. 2009;150(6):414-6.

132. Suwalsky M, Belmar J, Villena F, Gallardo MJ, Jemiola-Rzeminska M, Strzalka K. Acetylsalicylic acid (aspirin) and salicylic acid interaction with the human erythrocyte membrane bilayer induce in vitro changes in the morphology of erythrocytes. Arch Biochem Biophys. 2013;539(1):9-19.

133. Angiolillo DJ, Ferreiro JL. Antiplatelet and anticoagulant therapy for atherothrombotic disease: the role of current and emerging agents. Am J Cardiovasc Drugs. 2013;13(4):233-50.

134. Elblbesy MA, Hereba AR, Shawki MM. Effects of aspirin on rheological properties of erythrocytes in vitro. Int J Biomed Sci. 2012;8(3):188-93.

135. Gasparyan AY, Ayvazyan L, Pretorius E, Kitas GD. Platelets in rheumatic diseases: friend or foe? Curr Pharm Des. 2014;20(4):552-66.

136. Santos MT, Valles J, Lago A, Tembl J, Sanchez E, Moscardo A, et al. Residual platelet thromboxane $A 2$ and prothrombotic effects of erythrocytes are important determinants of aspirin resistance in patients with vascular disease. J Thromb Haemostasis. 2008;6(4):615-21.

137. Sostres C, Gargallo CJ, Lanas A. Aspirin, cyclooxygenase inhibition and colorectal cancer. World J Gastrointest Pharmacol Ther. 2014;5(1):40-9.

138. Berk M, Dean O, Drexhage H, McNeil JJ, Moylan S, Oneil A, et al. Aspirin: a review of its neurobiological properties and therapeutic potential for mental illness. BMC Med. 2013;11(1):74.

139. Kell DB, Pretorius E. Serum ferritin is an important inflammatory disease marker, as it is mainly a leakage product from damaged cells. Metallomics. 2014:4:748-73.
140. Pretorius E, Bester J, Vermeulen N, Lipinski B, Gericke GS, Kell DB. Profound morphological changes in the erythrocytes and fibrin networks of patients with hemochromatosis or with hyperferritinemia, and their normalization by iron chelators and other agents. PlosOne 2014. doi:10.1371/journal. pone.0085271. eCollection 2014.

141. Pretorius E, Kell DB. Diagnostic morphology: biophysical indicators for irondriven inflammatory diseases. Integr Biol. 2014;6:486-510.

142. Pretorius E, Vermeulen N, Bester J, Lipinski B, Kell DB. A novel method for assessing the role of iron and its functional chelation in fibrin fibril formation: the use of scanning electron microscopy. Toxicol Mech Methods. 2013;23(5):352-9.

143. Bester J, Buys AV, Lipinski B, Kell DB, Pretorius E. High ferritin levels have major effects on the morphology of erythrocytes in Alzheimer's disease. Front Aging Neurosci 2013. doi:10.3389/fnagi.2013.00088. eCollection 2013.

144. Pretorius E, Vermeulen N, Bester J. Atypical erythrocytes and platelets in a patient with a pro-thrombin mutation. Platelets. 2014;25(6):461-2.

145. American Diabetes Association. Standards of medical care in diabetes-2008. Diabetes Care. 2008;31 Suppl 1:S12-54.

146. Kuzuya T. Early diagnosis, early treatment and the new diagnostic criteria of diabetes mellitus. Br J Nutr. 2000;84 Suppl 2:S177-81.

147. Dufrêne YF, Martínez-Martin D, Medalsy I, Alsteens D, Müller DJ. Multiparametric imaging of biological systems by force-distance curvebased AFM. Nat Methods. 2013;10(9):847-54.

148. Kolar P, Tomankova K, Malohlava J, Zapletalova J, Vujtek M, Safarova K, et al. The effect of photodynamic treatment on the morphological and mechanical properties of the HeLa cell line. Gen Physiol Biophys. 2013;32 (3):337-46.

149. Berquand A. Quantitative imaging of living biological samples by PeakForce QNM atomic force microscopy. Bruker Appl Note. 2011;135:1-10.

150. Derjaguin B, Muller $V$, Toporov $Y$. Effect of contact deformations on the adhesion of particles. J Colloid Interface Sci. 1975;53:314-26.

151. Broadhurst D, Kell DB. Statistical strategies for avoiding false discoveries in metabolomics and related experiments. Metabolomics. 2006;2:171-96.

152. Rochester $C D$, Akiyode O. Novel and emerging diabetes mellitus drug therapies for the type 2 diabetes patient. World J Diab. 2014;5(3):305-15.

153. Resnick HE, Foster GL, Bardsley J, Ratner RE. Achievement of American Diabetes Association clinical practice recommendations among U.S. adults with diabetes, 1999-2002: the National Health and Nutrition Examination Survey. Diabetes Care. 2006;29(3):531-7.

154. Feldman BS, Cohen-Stavi CJ, Leibowitz M, Hoshen MB, Singer SR, Bitterman $\mathrm{H}$, et al. Defining the role of medication adherence in poor glycemic control among a general adult population with diabetes. PLoS One. 2014;9(9):e108145.

155. Williams JL, Walker RJ, Smalls BL, Campbell JA, Egede LE. Effective interventions to improve medication adherence in Type 2 diabetes: a systematic review. Diab Manag (London, England). 2014;4(1):29-48.

156. Yusuff KB, Obe O, Joseph BY. Adherence to anti-diabetic drug therapy and self management practices among type-2 diabetics in Nigeria. Pharm World Sci. 2008;30(6):876-83.

157. Gul N. Knowledge, attitudes and practices of type 2 diabetic patients. J Ayub Med Coll Abbottabad. 2010;22(3):128-31.

158. Adak S, Chowdhury S, Bhattacharyya M. Dynamic and electrokinetic behavior of erythrocyte membrane in diabetes mellitus and diabetic cardiovascular disease. Biochim Biophys Acta. 2008;1780(2):108-15.

159. Pretorius E, Swanepoel AC, Buys AV, Vermeulen N, Duim W, Kell DB. Eryptosis as a marker of Parkinson's disease. Aging-US 2014:In Press.

160. Kell DB, Pretorius E. The simultaneous occurrence of both hypercoagulability and hypofibrinolysis in blood and serum during systemic inflammation, and the roles of iron and fibrin(ogen). Integr Biol. $2014 ; 7: 24-52$. 